\title{
Review \\ Regulation of p53 and Cancer Signaling by Heat Shock Protein 40/J-Domain Protein Family Members
}

\author{
Atsushi Kaida ${ }^{1,2}$ and Tomoo Iwakuma ${ }^{2,3, *}$ \\ 1 Department of Oral Radiation Oncology, Graduate School of Medical and Dental Sciences, Tokyo Medical \\ and Dental University, Tokyo 113-8510, Japan; kai.mdth@tmd.ac.jp \\ 2 Department of Cancer Biology, University of Kansas Medical Center, Kansas City, KS 66160, USA \\ 3 Department of Pediatrics, Children's Mercy Research Institute, Kansas City, MO 64108, USA \\ * Correspondence: tiwakuma@cmh.edu
}

check for updates

Citation: Kaida, A.; Iwakuma, T. Regulation of p53 and Cancer Signaling by Heat Shock Protein 40/J-Domain Protein Family Members. Int. J. Mol. Sci. 2021, 22, 13527. https://doi.org/10.3390/ ijms222413527

Academic Editor: Nikolai A. Barlev

Received: 5 November 2021

Accepted: 14 December 2021

Published: 16 December 2021

Publisher's Note: MDPI stays neutral with regard to jurisdictional claims in published maps and institutional affiliations.

Copyright: (c) 2021 by the authors. Licensee MDPI, Basel, Switzerland. This article is an open access article distributed under the terms and conditions of the Creative Commons Attribution (CC BY) license (https:/ / creativecommons.org/licenses/by/ $4.0 /)$.

\begin{abstract}
Heat shock proteins (HSPs) are molecular chaperones that assist diverse cellular activities including protein folding, intracellular transportation, assembly or disassembly of protein complexes, and stabilization or degradation of misfolded or aggregated proteins. HSP40, also known as J-domain proteins (JDPs), is the largest family with over fifty members and contains highly conserved J domains responsible for binding to HSP70 and stimulation of the ATPase activity as a co-chaperone. Tumor suppressor p53 (p53), the most frequently mutated gene in human cancers, is one of the proteins that functionally interact with HSP40/JDPs. The majority of p53 mutations are missense mutations, resulting in acquirement of unexpected oncogenic activities, referred to as gain of function (GOF), in addition to loss of the tumor suppressive function. Moreover, stability and levels of wild-type p53 (wtp53) and mutant p53 (mutp53) are crucial for their tumor suppressive and oncogenic activities, respectively. However, the regulatory mechanisms of wtp53 and mutp53 are not fully understood. Accumulating reports demonstrate regulation of wtp53 and mutp53 levels and/or activities by HSP40/JDPs. Here, we summarize updated knowledge related to the link of HSP40/JDPs with p53 and cancer signaling to improve our understanding of the regulation of tumor suppressive wtp53 and oncogenic mutp53 GOF activities.
\end{abstract}

Keywords: HSP40; J-domain proteins; molecular chaperone; wild-type p53; mutant p53; tumor suppressor; cancer signaling

\section{Introduction}

Tumor suppressor p53 (p53) is a transcription factor that regulates the expression of genes involved in cell cycle arrest and apoptosis, thereby functioning as a tumor suppressor [1,2]. Under non-stressed conditions, the level and activity of wild-type p53 (wtp53) are tightly regulated at a low level mainly through its degradation by the E3 ubiquitin ligase MDM2. Upon genotoxic stresses, p53 protein is post-translationally modified by phosphorylation and acetylation to be stabilized and transcriptionally activated, leading to cell cycle arrest, senescence, and DNA repair for cell survival or apoptosis for cell death [3-7]. While p53 protein mainly localizes to the nucleus, p53 is also detected in the cytoplasm, endoplasmic reticulum (ER), and mitochondria, thereby contributing to a variety of cellular activities [8-12]. Thus, wtp53 prevents cells from undergoing tumorigenesis and is hence called the guardian of the genome [2]. Mutations in the $p 53$ gene are one of the most frequent events in human cancers [13]. The majority of p53 mutations are missense mutations with single amino acid changes in the DNA binding domain, resulting in the production of mutant p53 (mutp53) proteins. Mutp53 is roughly classified into two types, class I and class II, according to the sites of mutations [14]. Class I is a DNA contact type, in which a mutation occurs in amino acids that directly bind to the p53-responsive elements in DNA to impair the p53's sequence-specific DNA binding activity without robust changes in the protein structure. Class II is a structural or conformational type, in which a mutation 
results in a robust change in the p53 structure (misfolding), resulting in loss of the DNA binding activity, although not all mutants lose the DNA binding activity. Intriguingly, mutp53 not only loses wtp53's tumor suppressive functions, but also promotes cancer progression, metastasis, and drug resistance independent of wtp53, referred to as gain of function (GOF) [14-16]. The GOF mechanisms are mainly caused by binding of missense mutp53 with tumor suppressors (e.g., p63, p73, MRN complex) to inhibit their functions or with oncoproteins (e.g., ETS2, SREBP2, VDR, NF-Y) to enhance their functions [17-21]. Increasing evidence indicates that accumulation of mutp53 protein is crucial for oncogenic GOF activities. Increased levels of mutp53 by MDM2 depletion and genotoxic stress enhance the GOF activities, including cancer metastasis [22]. While mutp53 is stabilized or degraded by similar mechanisms as wtp53, several reports suggest the presence of distinct mechanisms of mutp53 stabilization or degradation from those of wtp53 [23-26]. Thus, the exact mechanisms behind the stabilization or degradation of wtp53 and mutp53 are not fully understood.

Molecular chaperones play a central role in protein quality control, which involves multiple cellular processes including protein synthesis, folding, unfolding, stabilization, and degradation, thus maintaining cellular homeostasis and protecting cells from endogenous and environmental genotoxic stresses, such as heat shock, hypoxia, infection, chemicals, and radiation $[27,28]$. Exposure of cells to stress prompts molecular chaperones to capture protein intermediates, which promotes the protein folding or refolding to prevent them from misfolding and aggregation $[25,29,30]$. Of various types of molecular chaperones, heat shock proteins (HSPs) are ubiquitously expressed in cells and are highly conserved among all organisms. In mammals, HSPs are classified into six families, based on the molecular size, including small HSPs, HSP40, HSP60, HSP70, HSP90, and HSP100. HSP70 and HSP90 are involved in protein folding or refolding, as well as stabilization or degradation, leading to control of cell cycle, proliferation, and apoptosis [31-35]. The activity of HSP70 must be precisely controlled to exert a wide range of functions. While the basal ATPase activity of HSP70 is low, HSP40, which is generally considered as a co-chaperone of HSP70, interacts with HSP70 and stimulates ATP hydrolysis together with client proteins [36,37]. Thus, binding of HSP40 is important to drive the HSP70 functions.

HSP40 is the largest family of the HSP families, consisting of over fifty members [37]. HSP40 is also known as J-domain proteins (JDPs) because it contains a highly conserved amino acid region, called "J domain". Especially, the most conserved sequence, His-ProAsp (HPD) motif, is crucial for stimulating the ATPase activity of HSP70 [38]. HSP40/JDPs are categorized into three groups: Class A (DNAJA), class B (DNAJB), and class C (DNAJC) (Figure 1). Class A and B HSP40/JDPs are comprised of the N-terminal J-domain, a Gly-Phe rich region, two C-terminal $\beta$-barrel domains (CTD I and CTD II) containing substratebinding regions, and a dimerization domain (Dim). A zinc-finger domain is further inserted into the CTD I in the class A HSP40/JDPs. Only a few of class B HSP40/JDPs (DNAJB1/HDJ1, DNAJB4/HLJ1, DNAJB5, DNAJB11/ERdj3/HEDJ) contain both the CTD II and dimerization domains, while other class B HSP40/JDPs lack either or both domains [37]. Any HSP40/JDPs that do not satisfy the criteria of either class A or B are classified into class $\mathrm{C}$. There is little similarity in the sequence except for the J domain of HSP40/JDPs, which may explain the diverse functions of HSP40/JDPs and the exquisite regulation of HSP70 activity [37]. In addition to functioning as a co-chaperone of HSP70, several HSP40/JDPs (e.g., bacterially purified Ydj1: Yeast DNAJA1/HDJ2 ortholog [39,40], human DNAJB1/HDJ1 [41], human DNAJB6/MRJ [42], human DNAJB8 [42], RSP16: C. reinhardtii DNAJB13 ortholog [43], bacterially purified mouse DNAJC10/ERdj5 [44], Cwc23: Yeast DNAJC17 ortholog [45]) have some functions independent of HSP70. The HSP70 independency is shown using in vitro purified systems without HSP70, HSP70-lacking cell-based assays, or mutant JDPs that cannot bind to HSP70 or lack an active J domain with mutations in the HPD motif. Importantly, HSP40/JDPs are the first line of molecular chaperones that detect misfolded proteins and protein aggregates. 


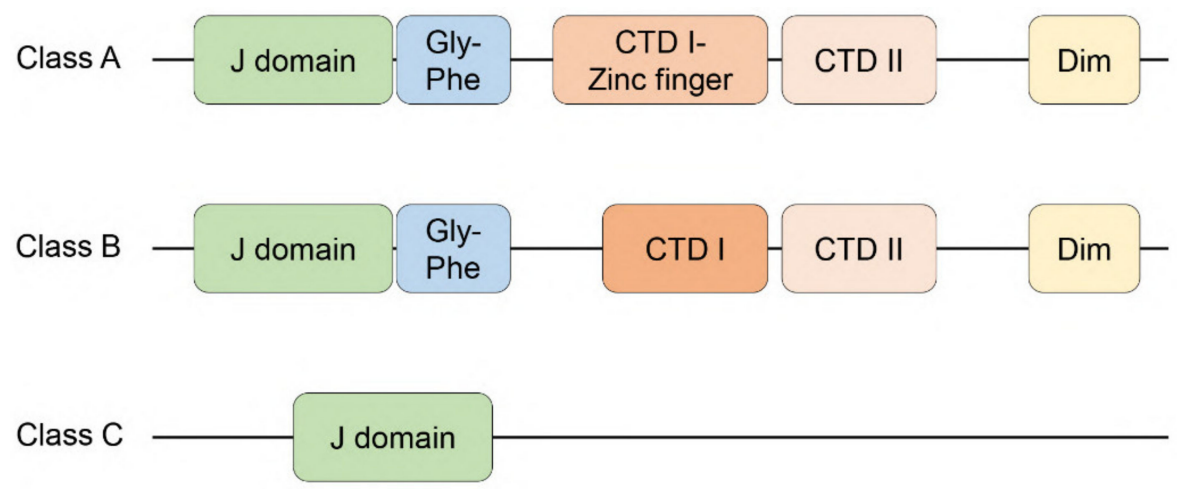

Figure 1. Structures of three types of HSP40/JDPs. Class A and B have the N-terminal J-domain, a Gly-Phe rich region (Gly-Phe), two C-terminal $\beta$-barrel domains (CTD I and CTD II), and a dimerization domain (Dim). A zinc-finger domain in the CTD I (CTD I-Zinc finger) is specific to the class A. Not all class B HSP40/JDPs contain CTD II and dimerization domains. J-domain containing proteins that do not fit to the criteria of class A or class B are classified as class C.

Increasing evidence indicates that HSP40/JDPs play roles in tumor suppression or progression, and some of them have been shown to regulate the levels and activities of wtp53 and mutp53. Intriguingly, the consequences of interactions between HSP40/JDPs and p53 are varied. A recent review article describes the effects of molecular chaperones on the wtp53 and mutp53 functions [25]. However, there is no review article summarizing the functional association of HSP40/JDPs with p53 and cancer signaling. Here, we focus on compiling reports related to the regulation of p53 activities and cancer progression by HSP40/JDPs, which may help design novel and appropriate targeted cancer therapies.

\section{Effects of HSP40/JDPs on p53 Activity and Cancer Signaling}

\subsection{Class A HSP40/JDPs (DNAJA Proteins)}

The class A HSP40/JDPs include DNAJA1, DNAJA2, DNAJA3, and DNAJA4 in mammals [37]. The roles of DNAJA1/HDJ2 and DNAJA3/Tid1 in cancer progression and regulation of p53 function are relatively well documented and are summarized below. DNAJA2 is implicated in cystic fibrosis and neurodegenerative diseases, mainly through degradation of misfolded cystic fibrosis transmembrane conductance regulator (CFTR) and inhibition of tau aggregation; however, its link to cancer development and p53 remains obscure [46-48]. Intriguingly, reduced mRNA expression of DNAJA4 by gene methylation is correlated with poor disease-free survival in stomach adenocarcinoma [49]. The hypermethylation status of DNAJA4 is also observed in pediatric embryonal and alveolar rhabdomyosarcoma [50]. However, little is known about the association of DNAJA4 with p53.

\subsubsection{DNAJA1/HDJ2}

DNAJA1, also known as HDJ2, is one of the best characterized HSP40/JDPs. DNAJA1/HDJ2 is implicated in a variety of diseases, including rheumatoid arthritis, oculopharyngeal muscular dystrophy, cystic fibrosis, and the neurodegenerative diseases $[46,48,51-54]$. This may be caused by DNAJA1's abilities to interact with key proteins involved in these diseases.

- DNAJA1/HDJ2 and cancer

DNAJA1/HDJ2 is also implicated in progression of multiple types of cancer [55-58]. A study suggests the tumor suppressive activity, in which knockdown of DNAJA1/HDJ2 promotes spheroid formation, migration, and invasion of $\mathrm{C} 6$ rat glioblastoma cells and reduces survival of rats bearing $\mathrm{C} 6$ tumor xenografts [59]. However, most studies indicate the oncogenic role of DNAJA1/HDJ2. High DNAJA1/HDJ2 mRNA expression is associated with poor survival in patients with breast cancer, while DNAJA1/HDJ2 promotes an antiapoptotic phenotype and invasiveness of pancreatic ductal adenocarcinoma cells [60,61]. 
DNAJA1/HDJ2 also promotes tumor growth and metastasis in human colorectal cancer (CRC) cell lines by interacting with and stabilizing cell division cycle 45 (CDC45) [56]. DNAJA1/HDJ2 also binds to an enzyme involved in extracellular matrix cross-linking and remodeling, transglutaminase 2 (TG2) that is associated with cell survival and cancer progression [62]. The anti-apoptotic activity of DNAJA1/HDJ2 is furthermore supported by a study showing that a DNAJA1-HSP70 complex inhibits nitric oxide-induced CHOPmediated apoptosis, in which farnesylated DNAJA1/HDJ2 binds to BAX and inhibits the translocation of BAX to mitochondria [63]. However, whether p53 is involved in the aforementioned tumor suppressive or oncogenic functions of DNAJA1/HDJ2 has not been investigated.

- $\quad$ DNAJA1/HDJ2 and p53

Recent studies suggest that DNAJA1/HDJ2 stabilizes misfolded or conformational type of mutp53 to promote cancer progression (Table 1). Our group and others show that DNAJA1/HDJ2 binds to misfolded/conformational mutp53 to prevent CHIP ubiquitin ligase-mediated proteasomal degradation of mutp53 [23,55,64,65]. Indeed, DNAJA1/HDJ2 depletion reduces the levels of several misfolded/conformational mutp53 (R156P, V157F, R175H, C176F, Y220C, G245S), but not DNA contact mutp53 (R248L, R248Q) or wtp53 $[23,55,65]$. Intriguingly, mutp53 levels are not affected by HSC70 knockdown in CAL33 cells carrying p53 ${ }^{\mathrm{R} 175 \mathrm{H}}$ [23], suggesting that stabilization of $\mathrm{p}^{\mathrm{R}}{ }^{\mathrm{R} 175 \mathrm{H}}$ by DNAJA1/HDJ2 could be independent of HSC70, although further studies are required to clarify the dependency on the HSP70 family. Moreover, DNAJA1/HDJ2 promotes migratory and colony-forming potential of head and neck cancer cell lines expressing misfolded/conformational mutp53 (R175H, C176F), but not cells with DNA contact mutp53 (R248L, R248Q), wtp53, or p53-null [65]. Co-immunoprecipitation studies reveal specific binding of DNAJA1/HDJ2 with misfolded/conformational mutp53 (R175H, C176F), but not DNA contact mutp53 (R248L), which supports the misfolded/conformational mutp53dependent function of DNAJA1/HDJ2 [65]. Intriguingly, prenylation of DNAJA1/HDJ2 is crucial for stabilizing the misfolded/conformational mutp53, since a C394S mutant DNAJA1/HDJ2 at the site of prenylation fails to rescue the reduced protein levels of p53 ${ }^{\mathrm{C} 176 \mathrm{~F}}$ in DNAJA1/HDJ2-knockout HN31 cells, unlike the full-length DNAJA1/HDJ2 [65], which is consistent with the previous observations $[55,64,66]$.

Table 1. Functional interactions between HSP40/JDPs and p53.

\begin{tabular}{|c|c|c|c|c|}
\hline HSP40/JDPs & $\begin{array}{l}\text { Type of p53 Proteins } \\
\text { Interacting with } \\
\text { HSP40/JDPs }\end{array}$ & Effects on p53 & $\begin{array}{l}\text { Dependency of HSP70 } \\
\text { (UD: Undetermined) }\end{array}$ & References \\
\hline \multirow[t]{2}{*}{ DNAJA1/HDJ2 } & $\begin{array}{c}\mathrm{p} 53^{\mathrm{R} 156 \mathrm{P}}, \mathrm{p} 53^{\mathrm{V} 157 \mathrm{~F}} \\
\mathrm{p} 53^{\mathrm{R} 175 \mathrm{H}}, \mathrm{p} 53^{\mathrm{C} 176 \mathrm{~F}} \\
\mathrm{p}^{\prime} 3^{\mathrm{Y} 220 \mathrm{C}}\end{array}$ & $\begin{array}{l}\text { DNAJA1/HDJ2 promotes oncogenic } \\
\text { functions (cell migration, colony-forming } \\
\text { potential) by interacting with and } \\
\text { stabilizing misfolded mutp53. It should be } \\
\text { noted that p53 }{ }^{\mathrm{R} 175 \mathrm{H}} \text { levels are not affected } \\
\text { by HSC70 knockdown in CAL33 cells. }\end{array}$ & $\begin{array}{l}\text { Stabilization of p53 } 3^{\mathrm{R} 175 \mathrm{H}} \\
\text { could be } \\
\text { HSC70-independent, } \\
\text { but the dependency on } \\
\text { HSP70 needs to be } \\
\text { clarified. }\end{array}$ & {$[23,55,64,65]$} \\
\hline & $\mathrm{p} 53^{\mathrm{R} 158 \mathrm{~L}}$ & $\begin{array}{l}\text { DNAJA1/HDJ2 confers radio-resistance in } \\
\text { SF763 cells. }\end{array}$ & UD & [67] \\
\hline DNAJA3/Tid1 & wtp53 & $\begin{array}{l}\text { Hypoxic and genotoxic stresses result in } \\
\text { formation of a complex of DNAJA3/Tid1 } \\
\text { and wtp53 through the J domain to } \\
\text { promote p53 mitochondrial localization } \\
\text { and transcription-independent apoptosis. }\end{array}$ & UD & {$[68,69]$} \\
\hline
\end{tabular}


Table 1. Cont.

\begin{tabular}{|c|c|c|c|c|}
\hline HSP40/JDPs & $\begin{array}{l}\text { Type of p53 Proteins } \\
\text { Interacting with } \\
\text { HSP40/JDPs }\end{array}$ & Effects on p53 & $\begin{array}{l}\text { Dependency of HSP70 } \\
\text { (UD: Undetermined) }\end{array}$ & References \\
\hline \multirow{4}{*}{ DNAJB1/HDJ1 } & wtp53 (via MDM2) & $\begin{array}{l}\text { The C-terminal region of DNAJB1/HDJ1 } \\
\text { binds to, stabilizes, and inhibits MDM2, } \\
\text { thus indirectly upregulating wtp53 activity. }\end{array}$ & Independent & [41] \\
\hline & wtp53 (via PDCD5) & $\begin{array}{l}\text { DNAJB1/HDJ1 inhibits wtp53's apoptotic } \\
\text { function through interaction with PDCD5 } \\
\text { and contributes to cancer progression. }\end{array}$ & UD & [70] \\
\hline & $\mathrm{p} 53^{\mathrm{R} 175 \mathrm{H}}$ & $\begin{array}{l}\text { DNAJB1/HDJ1 interacts with } \\
\text { conformational mutp53 (R175H), TAp73, } \\
\text { and HSP70. This complex enhances } \\
\text { chemo-resistance. }\end{array}$ & UD & [24] \\
\hline & $\mathrm{p} 53^{\mathrm{R} 175 \mathrm{H}}$ & $\begin{array}{l}\text { The interaction of DNAJB1/HDJ1 with } \\
\text { p53 }{ }^{\mathrm{R} 175 \mathrm{H}} \text { is enhanced by chetomin, which } \\
\text { restores the wtp53-like activity specifically } \\
\text { in TOV-112D and CAL33 cells. }\end{array}$ & UD & [71] \\
\hline \multirow{3}{*}{ DNAJB9/MDG1/ERdj4 } & wtp53 & $\begin{array}{l}\text { DNAJB9/MDG1/ERdj4 inhibits apoptosis } \\
\text { under genotoxic stress by interacting with } \\
\text { wtp53 through the J domain. }\end{array}$ & UD & [72] \\
\hline & wtp53 & $\begin{array}{l}\text { The interaction of DNAJB9/MDG1/ERdj4 } \\
\text { with p53 inhibits the H-RAS }{ }^{\text {12 }} \text {-induced } \\
\text { senescence and promotes transformation } \\
\text { in MEFs. }\end{array}$ & UD & [73] \\
\hline & wtp53 & $\begin{array}{l}\text { Site-specific mutations in the } \\
\text { DNAJB9/MDG1/ERdj4 gene in JEG-3 cells } \\
\text { reduce DNAJB9/MDG1/ERdj4 protein } \\
\text { levels with increased wtp53 levels. }\end{array}$ & UD & [74] \\
\hline DNAJC2/ZRF1 & wtp53 & $\begin{array}{l}\text { DNAJC2/ZRF1 inhibits wtp53's activity in } \\
\text { human gastric cancer cell lines carrying } \\
\text { wtp53, but not p53 mutations or p53 null. }\end{array}$ & UD & [75] \\
\hline DNAJC7/TPR2 & wtp53 & $\begin{array}{l}\text { DNAJC7/TPR2 inhibits colony-forming } \\
\text { potential by stabilizing wtp53 in H1299 } \\
\text { cells exogenously expressing wtp53. }\end{array}$ & UD & [76] \\
\hline
\end{tabular}

DNAJA1/HDJ2's transcription can be regulated by p53. An algorithm-based study predicts the presence of p53-responsive elements in the human DNAJA1/HDJ2's promoter, which is confirmed by chromatin-immunoprecipitation studies using MCF7 cells (wtp53) [77]. Moreover, a recent report shows that wtp53 indirectly represses mRNA expression of DNAJA1/HDJ2 by inhibiting phosphorylation of heat-shock factor 1 (HSF1), the master regulator of the proteotoxic stress response [78]. However, DNAJA1/HDJ2 levels are unchanged following exogenous introduction of wtp53 in mutp53-knockout HN31 cells [65]. Thus, regulation of DNAJA1/HDJ2 expression by p53 may be dependent on the experimental setting or cellular context.

- DNAJA1/HDJ2 as a cancer therapeutic target

Given the cancer-promoting role of DNAJA1/HDJ2, DNAJA1/HDJ2 can be a potential target for cancer therapy. Moreover, DNAJA1/HDJ2 is shown to confer radio-resistance in human SF763 glioblastoma cells (p53 ${ }^{\mathrm{R} 158 \mathrm{~L}}$ ) [67]. By screening the NCI-approved oncology drugs collection in human chronic myelogenous leukemia HAP1 cell line with or without DNAJA1/HDJ2 knockout, 41 compounds, including cabozantinib, clofarabine, and vinblastine, are identified as drugs that show synergy with DNAJA1/HDJ2 loss [79]. While neither of these studies examines the mutp53 dependency of the radio- and chemotherapyresistance, inhibition or depletion of DNAJA1/HDJ2 may increase the therapy efficacy. Since mutp53 increases radio- and chemotherapy-resistance [80-83], treatments of cancer cells carrying misfolded/conformational mutp53 with a DNAJA1/HDJ2 inhibitor may effectively increase the sensitivity to radio- and chemotherapies. Currently, no DNAJA1/HDJ2 inhibitor is clinically available, although 116-9e inhibits the DNAJA1/HDJ2 and HSP70 binding, and a chalcone compound, C86, appears to bind to and inhibit several HSP40/JDPs $[84,85]$. Identifying a compound that specifically inhibits DNAJA1/HDJ2 
or multiple HSP40/JDPs would accelerate the development of targeted cancer therapy, specifically for cancers expressing misfolded/conformational mutp53.

\subsubsection{DNAJA3 (Tid1: Tumorous Imaginal Disc 1)}

DNAJA3/Tid1 is mainly localized in the mitochondrial matrix to interact with mitochondrial HSP70 and their clients, and hence mitochondrial DNAJA3/Tid1 is responsible for maintaining mitochondrial DNA (mtDNA) integrity and mitochondrial membrane potential [86]. However, the splicing variants of DNAJA3/Tid1 (Tid1-S, Tid1-L) are localized in the cytosol [87]. While the exact functions of mitochondrial DNAJA3/Tid1 and the cytosolic variants remain to be elucidated, DNAJA3/Tid1 is involved in a variety of cellular processes, including proliferation, differentiation, senescence, survival, apoptosis, migration during embryonic development, skeletal muscle development, immunity, and viral infection [88-96]. Intriguingly, DNAJA3/Tid1 knockout mice develop dilated cardiomyopathy with decreased copy number of mtDNA in cardiomyocytes [97].

- DNAJA3/Tid1 and cancer

DNAJA3/Tid1 is implicated in cancer development. In head and neck cancers, high DNAJA3/Tid1 protein levels are correlated with favorable outcome with reduced malignancy and recurrence by inhibiting the galectin-7-TCF3-MMP9 axis or inhibiting the activities of EGFR and AKT [88,98]. Moreover, immunohistochemistry studies using breast cancer tissues show that DNAJA3/Tid1 levels are inversely correlated with tumor malignancy and ErbB2 levels through direct interaction with ErbB2 to promote CHIP-mediated proteasomal degradation [99]. In lung adenocarcinoma, reduced DNAJA3/Tid1 protein levels are correlated with poor overall survival and increased EGFR levels [100]. A recent study in human hepatocellular carcinoma shows that reduced DNAJA3/Tid1 protein levels are associated with increased Nrf2 protein levels and colony-forming potential of human HCC cells, as well as poor clinical outcomes after surgery [101]. In human gastric cancer, reduced DNAJA3/Tid1 expression is correlated with a poor prognosis and increased lymph node invasion in patients. Indeed, knockdown of DNAJA3/Tid1 in gastric cancer cells increases cell migration and invasion with increased protein stability of galectin-7 [86]. Additionally, DNAJA3/Tid1 is shown to interact with von Hippel-Lindau (VHL) protein to induce degradation of HIF- $1 \alpha$, leading to inhibition of VEGF expression and angiogenesis [102]. These observations support tumor suppressive functions of DNAJA3/Tid1. On the other hand, there are a few reports suggesting the oncogenic function of DNAJA3/Tid1. In CRC, increased DNAJA3/Tid1 levels are correlated with colon cancer progression [103]. In non-small cell lung carcinoma (NSCLC), Tid1-S, but not Tid1-L, is required for the EGF-stimulated EGFR transportation into mitochondria, potentially leading to enhanced cancer cell migration and invasion. Indeed, high levels of Tid1-S and EGFR in the mitochondria are correlated with lymph node metastasis and poor overall survival of NSCLC patients [104]. Thus, the roles of DNAJA3/Tid1 in cancer suppression or progression appear to be dependent on the type of cancer and the presence of the variants. However, whether the tumor suppressive or oncogenic functions of DNAJA3/Tid1 are dependent on p53 remains unclear.

\section{- $\quad$ DNAJA3/Tid1 and p53}

p53 is another binding partner of DNAJA3/Tid1 (Table 1). Upon hypoxic and genotoxic stress, DNAJA3/Tid1 binds to p53 through the J domain, promoting p53 mitochondrial localization and transcription-independent apoptosis in multiple cancer cell lines $[68,69]$. Intriguingly, overexpression of DNAJA3/Tid1 enhances mitochondrial translocation of multiple mutp53 (R175H, L194F, R273H, E285K) in several breast cancer and glioblastoma cell lines, resulting in increased mitochondrial apoptosis regardless of the presence of hypoxic stress [68]. Thus, DNAJA3/Tid1's binding to mutp53 may restore the transcription-independent mitochondrial apoptotic function of p53. Hence, increasing the DNAJA3/Tid1 levels or activity could be used as a strategy to induce apoptosis in p53-mutated cancers. 


\subsection{Class B HSP40/JDPs (DNAJB Proteins)}

There are 14 subtypes of DNAJB proteins in mammals. DNAJB proteins have similar domains to DNAJA proteins except that they lack the zinc finger domain within CTD I, and not all DNAJB proteins contain CTD II and dimerization domains (Figure 1). Regulation of HSP70 activity by DNAJB proteins appears to be through intrinsic blockade of the J domain by the Gly-Phe rich region. This blockade can be released by the interaction of the CTD I region of DNAJB1/HDJ1 with the C-terminal EEVD tetrapeptide of HSP70, which triggers the binding of HSP70 to the J domain of DNAJB1 to activate HSP70's ability to disaggregate amyloid fibrils [105]. Thus, DNAJB proteins exquisitely regulate HSP70 functions. DNAJB proteins are implicated in neuropathy (DNAJB2), muscular dystrophy or atrophy (DNAJB5, DNAJB6/MRJ), and primary ciliary dyskinesia (DNAJB13) [106-114]. Importantly, some DNAJB proteins, including DNAJB1/HDJ1, DNAJB4/HLJ1, DNAJB6/MRJ, DNAJB8, DNAJB9/MDG1/ERdj4, DNAJB11/ERdj3/HEDJ, and DNAJB12, are implicated in cancer progression [72,115-127]. Of these, DNAJB1/HDJ1 and DNAJB9/MDG1/ERdj4 are shown to bind to $\mathrm{p} 53$.

\subsubsection{DNAJB1/HDJ1}

DNAJB1/HDJ1 is the best characterized DNAJB member. DNAJB1/HDJ1 is involved in neurodegenerative diseases, inflammation, and viral replication through binding to proteins involved in these diseases. These include aggregation-prone tau conformers, $\alpha$-synuclein, melanoma differentiation-associated gene 5 (MDA5), and nucleoprotein component of influenza A virus ribonucleoproteins (RNPs) [128-131].

- DNAJB1/HDJ1 and cancer

DNAJB1/HDJ1 is also implicated in cancer progression and therapeutic resistance [24,132,133]. A fusion gene of DNAJB1/HDJ1 and PRKACA (protein kinase cAMP-activated catalytic subunit alpha), resulting from an $\sim 400 \mathrm{~kb}$ of in-frame deletion on chromosome 19, is found in nearly all cases of fibrolamellar hepatocellular carcinoma (FLHCC) [115]. As a mechanism, the DNAJB1-PRKACA fusion protein accelerates the FL-HCC tumorigenesis by cooperating with the WNT pathway [133]. Moreover, DNAJB1/HDJ1 binds to mitogen-inducible gene-6 (MIG6), a tumor suppressor that inhibits the EGFR signaling, which decreases the protein level of MIG6 by enhancing its ubiquitination, leading to upregulation of the EGFR signaling pathway in A549 lung adenocarcinoma and HCT116 CRC cell lines [132,134]. Additionally, DNAJB1/HDJ1 is identified as a biomarker for cholangiocarcinoma [135]. Thus, DNAJB1/HDJ1 promotes the progression of multiple types of cancer, although it remains to be determined whether p53 is involved in these oncogenic activities of DNAJB1/HDJ1.

- $\quad$ DNAJB1/HDJ1 and p53

DNAJB1/HDJ1 binds to and regulates the activities of both wtp53 and mutp53 (Table 1). An in vitro study using purified proteins reveals that DNAJB1/HDJ1 forms a complex with p53 (both wtp53 and p53 ${ }^{\mathrm{R} 175 \mathrm{H}}$ ) in the presence of HSC70 and ATP [136]. In support of this finding, Sugito et al. [137] observe the intracellular complex of p53 $3^{\mathrm{Y} 205 \mathrm{C}}$, DNAJB1/HDJ1, and HSP70 in human oral squamous cell carcinoma HOC815 cells. DNAJB1/HDJ1 appears to contribute to tumor suppression via regulation of the wtp53 activity. Specifically, DNAJB1/HDJ1 binds to and stabilizes MDM2, a major ubiquitin ligase of p53; however, this interaction inhibits MDM2's activity on p53, leading to p53 activation, while DNAJB1/HDJ1 knockdown increases cell proliferation and tumor growth of MCF7 cells in a manner dependent on wtp53 [41]. It should be noted that the C-terminal region of DNAJB1/HDJ1, lacking the J domain, is sufficient for interacting with and stabilizing MDM2, suggesting that DNAJB1-mediated stabilization of MDM2 is likely HSP70 independent. Silva et al. [138] also observe that DNAJB1/HDJ1, whose mRNA and protein levels are induced by trans-chalcone (TChal), binds to wtp53, leading to stabilization and activation of wtp53 in U2OS cells. These findings suggest the tumor suppressive role of DNAJB1/HDJ1. 
However, Cui et al. [70] show that DNAJB1/HDJ1 binds to and induces degradation of Programmed Cell Death 5 (PDCD5), a positive regulator of p53-mediated apoptosis, in HCT116 cells, while knockdown of DNAJB1/HDJ1 enhances etoposide-mediated inhibition of colony formation with an increase in the PDCD5 levels and cell death in A549 cells. These results suggest that DNAJB1/HDJ1 inhibits wtp53's apoptotic function through interaction with PDCD5 and contributes to cancer progression. Thus, the effects of DNAJB1/HDJ1 on the wtp53 activity are dependent on the cellular context or experimental settings.

Some studies have examined the functional interaction between DNAJB1/HDJ1 and oncogenic mutp53. Specifically, DNAJB1/HDJ1, together with HSP70, appears to facilitate binding of conformational mutp53 (R175H) with TAp73, a p53 family member. This complex induces chemoresistance to several DNA damaging reagents. Intriguingly, when MDM2 is overexpressed in cells carrying mutp53, this complex is inhibited by MDM2, which switches to the formation of mutp53-TAp73-MDM2 complex, leading to furthermore enhanced resistance to cisplatin, etoposide, and doxorubicin in SkBr3 and H1299 cells expressing p53 ${ }^{\mathrm{R} 175 \mathrm{H}}$ [24]. This could explain why breast cancer patients with p53 mutations and high levels of MDM2 show poorer overall survival than those with p53 mutations or MDM2 overexpression alone [24]. The observation that DNAJB1/HDJ1 supports mutp53's oncogenic GOF is also supported by a report by Parrales et al. [23] in which DNAJB1/HDJ1 contributes to the accumulation of $\mathrm{p} 53^{\mathrm{R} 175 \mathrm{H}}$.

Intriguingly, Hiraki et al. [71] identify a natural compound, chetomin (CTM) as a compound that enhances the interaction of DNAJB1/HDJ1 with $\mathrm{p} 53^{\mathrm{R} 175 \mathrm{H}}$ to restore the wtp53-like activity. CTM inhibits cell proliferation and tumor growth specifically in TOV$112 \mathrm{D}$ and CAL33 cells carrying $\mathrm{p} 53^{\mathrm{R} 175 \mathrm{H}}$ with mRNA upregulation of $\mathrm{p} 53$ target genes, $p 21$, $P U M A$, and $M D M 2$, and increased DNA binding activity of $\mathrm{p} 53^{\mathrm{R} 175 \mathrm{H}}$ to $\mathrm{p} 53$-responsible elements in these genes. Thus, the interaction of DNAJB1/HDJ1 with $\mathrm{p} 53^{\mathrm{R} 175 \mathrm{H}}$ induced by CTM may promote refolding of $\mathrm{p} 53^{\mathrm{R} 175 \mathrm{H}}$, rather than enhancing mutp53 GOF activity or stability as observed by other reports $[23,24]$. Since these experiments are not tested using cells lacking DNAJB1/HDJ1, it remains unclear whether the biological activity and mutp53 reactivation by CTM are solely dependent on DNAJB1/HDJ1. The discrepancies may be caused by the unappreciated function of CTM or differences in the cellular context. Together, whether DNAJB1/HDJ1 functions as a tumor suppressor or an oncogene appears to be dependent on the presence of wtp53 or mutp53, experimental settings, and the cellular context.

\subsubsection{DNAJB9/MDG1/ERdj4}

DNAJB9/MDG1/ERdj4 localizes to the ER and is upregulated by ER stress [139]. DNAJB9/MDG1/ERdj4 binds to and co-localizes with 78-kDa glucose-regulated protein (GRP78)/binding immunoglobulin protein (BiP), an ER chaperone in the HSP70 family member $[139,140]$. DNAJB9/MDG1/ERdj4 protects cells from ER stress and inhibits cell death, likely through stimulating the GRP78/BiP activity and stabilizing the GRP78/BiP's binding to unfolded substrate proteins for protein folding. DNAJB9/MDG1/ERdj4 is also involved in the ER-associated degradation (ERAD) system by interacting with some ERAD substrates (misfolded surfactant protein C: SP-C, CFTR) and promotes their degradation [141,142]. Intriguingly, DNAJB9/MDG1/ERdj4 in the ER lumen promotes ERAD of a lipogenic transcription factor SREBP1c to inhibit lipogenesis, while DNAJB9/MDG1/ERdj4 in the ER membrane promotes the mTORC2 complex assembly in the cytosol to stimulate protein and ATP synthesis [143]. Indeed, overexpression of DNAJB9/MDG1/ERdj4 in the liver improves insulin sensitivity, restores protein synthesis, and reduces hepatic steatosis and adiposity in obese mouse models [143].

- DNAJB9/MDG1/ERdj41 and cancer

DNAJB9/MDG1/ERdj4 also plays a role in tumor suppression. In breast cancers, the DNAJB9/MDG1/ERdj4 mRNA level is lower than that in normal breast tissues, which is correlated with poor clinical outcomes [144]. Moreover, DNAJB9/MDG1/ERdj4 binds to and stabilizes F box/SPRY domain-containing protein 1 (FBXO45) to promote FBXO45- 
mediated ubiquitination and degradation of zinc finger E-Box binding homeobox 1 (ZEB1), leading to inhibition of migratory, invasion, and in vivo metastases of MDA-MB-231 cells [144]. However, involvement of p53 in these phenotypes has not been investigated.

- $\quad$ DNAJB9/MDG1/ERdj41 and p53

DNAJB9/MDG1/ERdj4 also interacts with wtp53 (Table 1). Lee et al. [72] show that DNAJB9/MDG1/ERdj4, whose mRNA expression is indirectly induced by wtp53, binds to wtp53 and inhibits p53-mediated apoptosis under genotoxic stress. While a DNAJB9/MDG1/ERdj4 mutant lacking the J domain cannot bind to wtp53, whether HSP70 is involved in the observed p53 inhibition by DNAJB9/MDG1/ERdj4 needs to be clarified. The same group also shows that DNAJB9/MDG1/ERdj4 overexpression inhibits the H-RAS ${ }^{\mathrm{V} 12}$-induced p53-dependent senescence in MEFs and promotes the cellular transformation [73]. In support of these findings, in human non-gestational choriocarcinoma samples, two missense mutations in the DNAJB9/MDG1/ERdj4 gene are found (F46Y, H47R), while the introduction of site-specific mutations in the DNAJB9/MDG1/ERdj4 gene in gestational choriocarcinoma JEG-3 cells results in reduced DNAJB9/MDG1/ERdj4 mRNA and protein levels with increase in the wtp53 levels [74]. These studies suggest the tumor-promoting function of DNAJB9/MDG1/ERdj4 by inhibiting wtp53, which is distinct from the aforementioned tumor-suppressive function of DNAJB9/MDG1/ERdj4 in breast cancer by Kim et al. [144]. Thus, the roles of DNAJB9/MDG1/ERdj4 in cancer suppression or progression could be dependent on the presence of wtp53 in cells or other cellular contexts.

\subsubsection{Other DNAJB Members and Cancer}

- DNAJB4/HLJ1

DNAJB4/HLJ1 is not only implicated in myocardial infarction and Alzheimer's disease $[145,146]$, but also regulates cancer progression. In NSCLC and CRC, DNAJB4/HLJ1 levels are inversely correlated with clinical outcomes [147,148]. In invasive breast carcinoma, the DNAJB4/HLJ1 level is significantly lower, as compared to normal breast tissues, benign neoplasm, and ductal carcinoma in situ [149]. Tsai et al. [147] also show that exogenous expression of DNAJB4/HLJ1 reduces invasion, migration, proliferation, colony formation, and primary tumor growth of lung adenocarcinoma cells with increasing p21 levels; however, these phenotypes are p53-independent [147]. Overall, DNAJB4/HLJ1 functions as a tumor suppressor, but its functional relationship with p53 remains unclear.

- DNAJB6/MRJ

DNAJB6/MRJ is another DNAJB member implicated in cancers. High levels of DNAJB6/MRJ are associated with poor outcomes in patients with CRC, while knockdown of DNAJB6/MRJ in HCT116 and SW480 CRC cells inhibits invasion and pulmonary metastases with reduced IQ Motif Containing GTPase Activating Protein 1 (IQGAP1) levels, a scaffold protein of the MAP kinase pathway [123]. Lin et al. [150] also show that DNAJB6/MRJ promotes cell adhesion, migration, and invasion through stabilizing uPAR, as well as phosphorylation of FAK, ERK1/2, and AKT, in HCT116 cells. These reports suggest oncogenic roles of DNAJB6/MRJ. However, in breast cancer cells, DNAJB6/MRJ inhibits cancer progression by binding to HSPA8 and inhibiting Wnt/ $\beta$-catenin signaling and epithelial-mesenchymal transition (EMT) [120,151,152]. Moreover, in esophageal squamous cell carcinoma (ESCC), nuclear localization of DNAJB6/MRJ is associated with favorable outcomes in patients with ESCC, while DNAJB6a, an isoform that contains a nuclear localization signal, reduces proliferation and xenograft tumor growth with reduced AKT signaling [122]. Thus, the function of DNAJB6/MRJ may be dependent on tissue type or the presence of the isoforms. Whether DNAJB6/MRJ has any impact on p53 activity needs to be determined as a future study. 


\section{- $\quad$ DNAJB8}

DNAJB8 functions to protect against protein toxicity associated with polyQ aggregation diseases $[153,154]$. DNAJB8 is also identified as a factor that induces cancer stem-like properties, such as tumor-initiating ability and drug resistance in human CRC and renal cell carcinoma (RCC) cell lines $[124,155,156]$. However, the underlying mechanisms and the potential involvement of p53 remain to be elucidated.

- DNAJB11/ERdj3/HEDJ

DNAJB11/ERdj3/HEDJ is localized in ER and is associated with glomerular disease, autosomal-dominant polycystic kidney disease, and Gaucher's disease [157-160]. DNAJB11/ERdj3/HEDJ is also upregulated in oral squamous cell carcinoma and hepatocellular carcinoma tissues [126,161]. Intriguingly, DNAJB11/ERdj3/HEDJ, together with HSP90, forms a complex with K1, a transmembrane glycoprotein encoded in the Kaposi sarcoma-associated herpesvirus (KSHV) genome, which is critical for the anti-apoptotic function of K1 in Kaposi sarcoma and other KSHV-related diseases [162]. It remains unclear whether the anti-apoptotic function of DNAJB11/ERdj3/HEDJ could be due to inhibition of p53 activity.

\section{- $\quad$ DNAJB12}

DNAJB12 is also an ER-associated HSP40/JDP [163]. ER stress induces degradation of DNAJB12 by the ubiquitin-proteasome pathway via ERAD complexes containing homocysteine-inducible ER protein (HERP), a suppressor/enhancer of Lin-12-like (Sel1L), and glycoprotein 78 (gp78) [127]. Intriguingly, DNAJB12 complexes with gp78 and Bcl-2 related ovarian killer (BOK), an ER-associated BCL-2 family member that regulates ER stress-induced apoptosis [127]. Depletion of DNAJB12 in Huh-7 hepatocellular carcinoma cells enhances apoptosis induced by proteotoxic agents and a proapoptotic chemotherapeutic agent (LCL-161), with an accumulation of BOK and caspase activation. There is no report showing any link between DNAJB12 and p53 [127].

\subsection{Class C HSP40/JDPs (DNAJC Proteins)}

Any HSP40/JDPs, which do not belong to either class A or B, are categorized into class C. The class C HSP40/JDPs are comprised of at least 32 members with the greatest diversity in their molecular sizes, structures, and functions [37,164]. While DNAJC proteins are implicated in a variety of diseases, limited studies have shown their roles in cancer progression $[165,166]$. Of 32 DNAJC members, DNAJC12, DNAJC15/MCJ, and DNAJC25 are implicated in cancer progression, while members linked to p53 include DNAJC2/ZRF1, DNAJC7/TPR2, and DNAJC9.

\subsubsection{DNAJC2/ZRF1}

DNAJC2, also known as ZRF1 (Zuotin-Related Factor 1), is identified as a human ribosome-associated JDP that forms a complex with HSP70 and has been characterized as an epigenetic gene transcription regulator of stemness, development, and differentiation $[167,168]$. Mechanistically, DNAJC2/ZRF1 binds to ubiquitinated histone H2A and displaces the polycomb-repressive complex 1 (PRC1) from chromatin, leading to transcriptional activation $[169,170]$.

\section{- DNAJC2/ZRF1 and cancer}

DNAJC2/ZRF1 is shown to enhance H-Ras-induced cellular senescence of MEFs by interacting with the INK4/ARF locus and upregulating p16 ${ }^{\mathrm{INK} 4 \mathrm{a}}$ mRNA expression, thus displaying the tumor suppressive function. Knockdown of DNAJC2/ZRF1, indeed, enhances H-Ras-mediated transformation of MEFs [171].

On the other hand, DNAJC2/ZRF1 is overexpressed in human acute myelocytic leukemia (AML), and depletion of DNAJC2/ZRF1 results in decreased cell proliferation with increased apoptosis and cell differentiation, thus showing oncogenic function [172]. This may be caused, at least partially, by its binding to retinoic acid receptor $\alpha(\operatorname{RAR} \alpha)$, since 
DNAJC2/ZRF1 knockdown enhances RA-mediated suppression of HL60 xenografts [172]. DNAJC2/ZRF1 protein levels are also upregulated in gastric cancer tissues as compared to non-tumor tissues, which is correlated with poor overall outcomes [75].

- $\quad$ DNAJC2/ZRF1 and p53

DNAJC2/ZRF1's oncogenic function may be dependent on p53. Knockdown of DNAJC2/ZRF1 in human gastric cancer cell lines inhibits cell proliferation and migration and induces apoptosis with increased p21 levels, especially when cells carry wtp53 (Table 1). These phenotypes are minimally observed in cancer cells with p53 mutations and p53 null [75], suggesting that DNAJC2/ZRF1 inhibits the function of wtp53 to promote cancer progression. Thus, DNAJC2/ZRF1 acts as either a tumor suppressor or an oncogene, depending on the cellular context, including the cancer type and/or the presence of wtp53 in cells.

\subsubsection{DNAJC7/TPR2}

DNAJC7, also known as Tetratricopeptide Repeat 2 (TPR2), contains two TPR domains that bind to both HSP70 and HSP90, in addition to the J domain for stimulating ATP hydrolysis and polypeptide binding by HSP70 [173]. Accumulating studies suggest the involvement of DNAJC7/TPR2 in amyotrophic lateral sclerosis (ALS), likely through binding to natively folded tau and inhibiting tau aggregation $[165,174,175]$. DNAJC7/TPR2 binds to many other proteins, together with HSP70, including progesterone receptor, RAD9, a U-box E3 ubiquitin ligase UFD2a, and constitutive active androstane receptor (CAR)/Nuclear Receptor Subfamily 1 Group I Member 3 (NR1I3) [176-179]. However, the biological consequence of these interactions remains unclear.

- DNAJC7/TPR2 and cancer

DNAJC7/TPR2 is also implicated in cancer progression. Increased polyglutamylatedDNAJC7/TPR2 levels in sera may serve as a potential biomarker for early detection of RCC and are also associated with advanced stage and grade of RCC [180]. However, the underlying mechanism remains unclear.

- $\quad$ DNAJC7/TPR2 and p53

Kubo et al. [76] identify DNAJC7/TPR2 as a regulator of p53. DNAJC7/TPR2 binds to the DNA binding domain of p53. This interaction stabilizes and activates p53, leading to inhibition of the colony-forming potential of $\mathrm{H} 1299$ cells exogenously expressing wtp53, with increased p21, BAX, and MDM2 mRNA levels. Future studies are required to determine whether the tumor suppressive function of DNAJC7/TPR2 is entirely dependent on p53 or if DNAJC7/TPR2 could show any oncogenic functions in different experimental settings or cellular contexts.

\subsubsection{DNAJC9}

DNAJC9 activates the HSP70's ATPase activity through the J domain as other HSP40/JDPs. DNAJC9 mRNA and protein levels are upregulated by various stress and mitogenic stimuli [181]. DNAJC9 mainly localizes to the nucleus; however, upon heat shock stress, DNAJC9 is exported to the cytoplasm and plasma membrane [181]. Recently, Hammond et al. [182] demonstrate that DNAJC9 forms a complex with a DNA replication licensing factor MCM2 and a histone $\mathrm{H} 3-\mathrm{H} 4$ dimer to recruit multiple HSP70 enzymes and fold histone H3-H4 dimers, for maintenance of a proper supply of histones during active replication and transcription. Intriguingly, DNAJC9 is implicated in familial recurrent corneal erosion dystrophy, epithelial recurrent erosion dystrophy, and schizophrenia [183,184].

- DNAJC9 and cancer

DNAJC9 is also implicated in cancer progression. DNAJC9 is upregulated in basal, HER2, and luminal B breast cancers, as well as in node-positive cervical squamous cell carcinoma [185]. By comprehensive analysis of transcriptomic profiles of HSP family genes 
in 9018 patients with 28 cancers, Liu et al. [186] show that DNAJC9 mRNA is upregulated in multiple different cancer types with prognostic values. These include adrenocortical carcinoma, AML, prostate adenocarcinoma, and lung adenocarcinoma. However, how DNAJC9 contributes to cancer progression remains to be elucidated.

- $\quad$ DNAJC9 and p53

While there is no report showing the regulation of p53 activity by DNAJC9, DNAJC9 appears to be a downstream target of p53 in the zebrafish system; an in silico screening of the zebrafish genome identifies a p53-responsive element in the zebrafish DNAJC9 gene [187]. The chromatin-immunoprecipitation and luciferase reporter assays further confirm the interaction of p53 with the promoter region of the zebrafish DNAJC9 gene.

\subsubsection{Other DNAJC Members and Cancer}

\section{- DNAJC12}

DNAJC12 is implicated in dystonia and intellectual disability [188], mild hyperphenylalaninemia [188-190], and Parkinson disease in the Chinese Han population [191]. Some oncogenic roles of DNAJC12 have also been reported. In rectal cancer, increased DNAJC12 levels are correlated with poor chemotherapy response [192]. In gastric cancer, increased mRNA expression of DNAJC12 is correlated with cancer invasion, lymph node metastasis, and disease progression, thus having higher morbidity and mortality rates [193]. Moreover, in lung cancer, DNAJC12 levels are upregulated, while DNAJC12 knockdown reduces the malignant properties and tumor growth of lung cancer cells in vitro and in vivo by inhibiting activation of $\beta$-catenin [194]. However, none of these studies address if there is a link with p53.

- DNAJC15/MCJ

DNAJC15/MCJ is a unique member that localizes at the mitochondrial inner membrane. DNAJC15/MCJ functions as a negative regulator of the respiratory chain and inhibits the complex I activity and mitochondrial membrane potential, promoting ROS overproduction and ATP depletion [195]. DNAJC15/MCJ potentially acts as a tumor suppressor by promoting the release of pro-apoptotic molecules through the mitochondrial permeability transition pore complex [196]. Indeed, DNAJC15/MCJ is frequently hyper-methylated in multiple types of human cancer, including malignant pediatric tumors, neuroblastoma, Wilm's tumor, melanoma, and breast cancer [197-200]. Reduced expression of DNAJC15/MCJ is also correlated with increased drug resistance, as well as increased levels of c-JUN protein and its downstream target ATP binding cassette subfamily B member 1 (ABCB1)/multiple drug resistance 1 (MDR1), in ovarian and breast cancers [200-203]. Whether p53 is involved in the tumor suppressive function of DNAJC15/MCJ has not been investigated.

- DNAJC25

DNAJC25 is relatively a new member of the HSP40/JDP subfamily C, and hence little is known about the function of this protein. In liver cancers, DNAJC25 mRNA expression is markedly reduced, while its overexpression induces apoptosis and inhibits colony formation of liver cancer cells [204]. In silico analyses suggest that DNAJC25 mRNA expression is also reduced in breast cancer tissues, and high DNAJC25 mRNA expression is correlated with favorable post-progression survival in breast cancer [205]. These results suggest the tumor suppressive role of DNAJC25, but the functional association of DNAJC25 with p53 remains to be elucidated.

\section{Discussion}

Both wtp53 and mutp53 proteins can be misfolded under a variety of cellular conditions (e.g., heat shock, genotoxic stress) like other proteins. These misfolded proteins as well as properly folded native proteins are detected by molecular chaperone systems, including HSPs, to be refolded, stabilized, or degraded. Indeed, both wtp53 and mutp53 
are bound to and functionally regulated by the HSP system [206-211]. Since the HSP system has a great impact on the protein levels and functions, understanding the mechanisms by which HSPs detect and regulate the structure and functions of wtp53 and mutp53 would help design efficient p53-targeted anti-cancer therapies. At least fifty members of HSP40/JDPs are present in cells, and each has different clients [37]. This may explain the diverse regulation of target proteins including $\mathrm{p} 53$ by HSP40/JDPs and different biological outcomes. Several literatures suggest HSP70-independent functions of HSP40/JDPs in in vitro and in vivo $[39,40,42-45]$. Hence, whether the oncogenic or tumor suppressive functions of each HSP40/JDP are HSP70-dependent or -independent needs to be clarified in the future.

Recent studies suggest that wtp53 acts like mutp53 under specific conditions, referred to as pseudo-mutant p53. Indeed, previous studies indicate that wtp53 could be misfolded and form a mutant conformation, especially in the absence of specific chaperones, leading to reduced wtp53 transcriptional activity and cancer progression [212-214]. To support this finding, Arandkar et al. [215] observe that wtp53 in cancer-associated fibroblasts (CAFs), but not in normal fibroblasts, acquires misfolded conformation and rather enhances migration, invasion, and tumor growth of lung cancer cells. Moreover, a small subset of breast cancers with wtp53 display gene expression patterns similar to those carrying mutp53, including upregulation of genes specifically regulated by mutp53 (e.g., PSAT1, TAP1, AurkA, CDC45, MAD2L1, ATL3) [216]. Additionally, in a subpopulation of preleukemic hematopoietic stem/progenitor cells from primary human AML that carry DNA (cytosine-5)-methyltransferase 3 alpha (DNMT3A) mutations, high levels of pseudo-mutant p53 are dominantly detected over the wild-type conformation, while p53 in leukemic blasts shows mainly the wtp53 conformation [217]. It remains unknown how and under which conditions wtp53 conformation converts to mutant conformation and whether the process is reversible. Given the role of HSP40s/JDPs in protein folding and refolding, some members of HSP40s/JDPs could be involved in this process.

Mutp53 can be reactivated by heat shock, second-site mutations, and chemical compounds, leading to restoration of the wtp53 activity. Specifically, temperature-sensitive mutp53 (e.g., A135V, V143A, G245S, R249S), which mainly localizes to the cytoplasm, relocates to the nucleus to be reactivated upon lowering temperature. Akakura et al. [218] show that HSC70 is associated with p53 $3^{\mathrm{A} 135 \mathrm{~V}}$ at $37^{\circ} \mathrm{C}$, but not at $32^{\circ} \mathrm{C}$, while the HSC70containing complex masks the nuclear localization signal of mutp53 at $37^{\circ} \mathrm{C}$ to prevent mutp53 from nuclear translocation. Moreover, a second-site mutation (e.g., H168R) reverts some of the chemical shift changes caused by the original mutation (e.g., R249S), leading to restoration of wtp53 conformation and the DNA binding activity [219]. Additionally, several chemical compounds have been identified to restore the wtp53 activity from mutp53. These include PRIMA-1MET, CTM, and SLMP53-2 [71,220-222]. PRIMA-1MET, that induces mutp53 reactivation and mutp53-dependent apoptosis, promotes nucleolar localization of mutp53, together with promyelocytic leukemia protein (PML) nuclear bodyassociated proteins (PML, cAMP responsive binding protein: CBP, HSP70), which may play a role in mutp53 reactivation [221,222]. As mentioned in the DNAJB1/HDJ1 section, CTM binds to DNAJB1/HDJ1 to reactivate p53 ${ }^{\mathrm{R} 175 \mathrm{H}}$ [71]. SLMP53-2 is identified as a compound that inhibits viable cell proliferation of $\mathrm{H} 1299$ cells exogenously expressing mutp53 (R175H, Y220C, G245S, R280K) [220]. This compound restores wt-like conformation of mutp53 (Y220C) by enhancing the binding with HSP70, leading to upregulation of p53's downstream target gene expression [220]. By acting as a co-chaperone of HSP70 and/or detecting misfolded protein structure, some HSP40/JDP members could regulate mutp53 reactivation.

Understanding the mechanism of p53 regulation by HSP40/JDPs is crucial for developing novel p53-targeted therapies, given that current wtp53- and mutp53-targeting therapies have not yet been successful. Increasing the wtp53 activity specifically in tumors is required for successful targeted cancer therapy. For mutp53-expressing cancers, depletion or reactivation of mutp53 should be achieved without activating wtp53 in non-tumor 
cells. Given that HSP40/JDPs play central roles in the stabilization or degradation of wtp53 and mutp53, as well as reactivation of mutp53, controlling the p53 (wtp53, mutp53) levels and activity via HSP40/JDPs could be an alternative strategy for cancer therapy, instead of directly targeting p53.

\section{Conclusions}

We have given an overview of HSP40/JDPs mainly by focusing on their roles in cancer signaling and p53 functions (Figure 2 and Table 1). HSP40/JDPs detect misfolded structures of proteins and alter their localization, stability, or functions, therefore involved in numerous diseases including cancers. The activities of wtp53 and mutp53 can be fine-tuned by multiple HSP40s/JDPs, partially explaining diverse p53 functions in various cellular contexts and tumor microenvironments. Until now, only six HSP40/JDPs (DNAJA1, A3, B1, B9, C2, C7) have been found to regulate wtp53 and/or mutp53 activities, though 16 members are implicated in cancer progression. Identifying more HSP40/JDPs involved in cancer progression and p53 (wtp53, mutp53) activities, as well as the underlying mechanisms, will advance our knowledge of cancer progression and may accelerate the development of novel anti-cancer therapies.
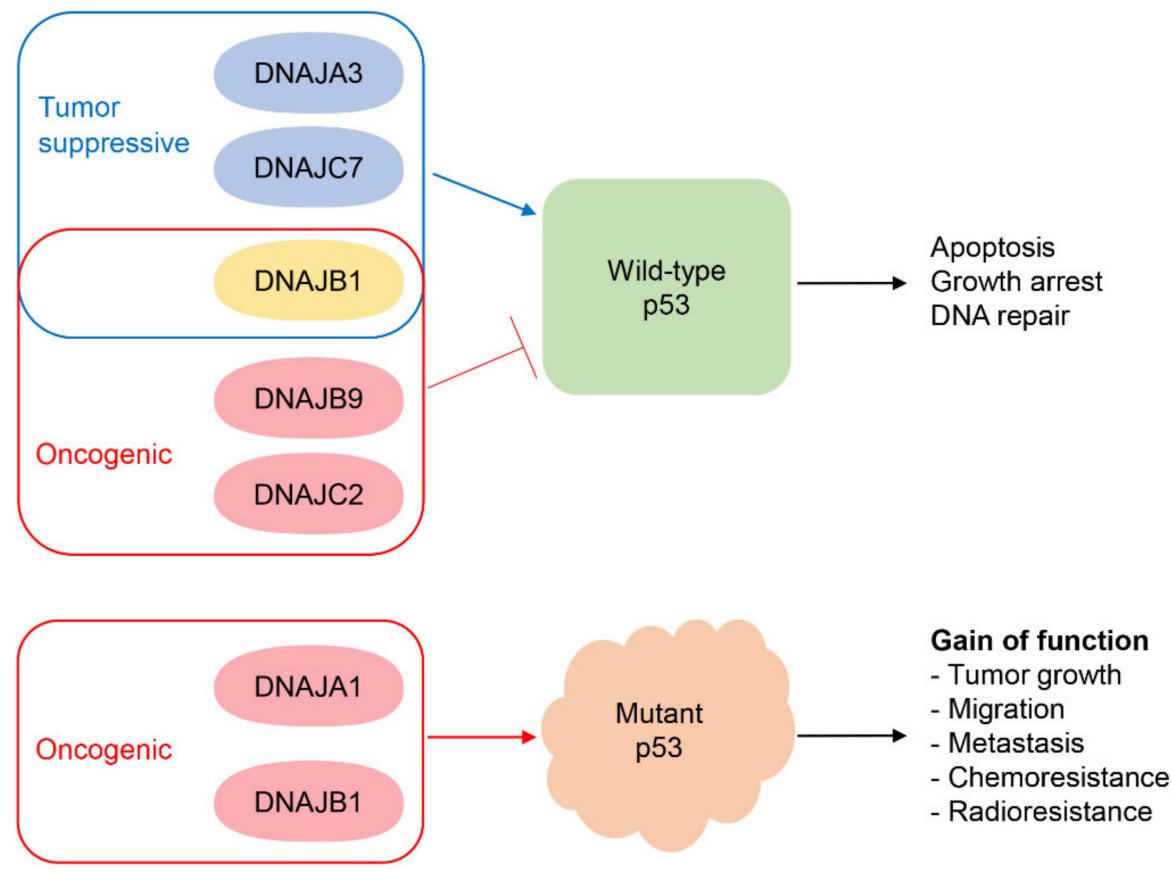

Figure 2. Regulation of wtp53 and mutp53 functions by HSP40/JDPs. DNAJA3 and DNAJC7 cooperate with wtp53 to enhance the tumor suppressive activity, while DNAJB9 and DNAJC2 have tumor-promoting functions by inhibiting the wtp53 activity. DNAJB1 can inhibit or enhance the wtp53 activity, likely depending on the cellular context and/or cancer type. DNAJA1 and DNAJB1 interact with mutp53 and contribute to the levels and activity of GOF mutp53.

Author Contributions: A.K. and T.I. summarized the literatures and wrote the manuscript. All authors have read and agreed to the published version of the manuscript.

Funding: T.I. was supported by NIH-NCI (R01CA214916) and Braden's Hope for Childhood Cancer. Institutional Review Board Statement: Not applicable.

Informed Consent Statement: Not applicable.

Data Availability Statement: Not applicable.

Acknowledgments: We thank Shigeto Nishikawa and Elizabeth Thoenen for critical reading of the manuscript, and they have consented to the acknowledgement. 
Conflicts of Interest: The authors declare no conflict of interest.

\section{References}

1. Vogelstein, B.; Lane, D.; Levine, A.J. Surfing the p53 network. Nature 2000, 408, 307-310. [CrossRef] [PubMed]

2. Lane, D.; Levine, A. p53 Research: The past thirty years and the next thirty years. Cold Spring Harb. Perspect. Biol. 2010,2 , a000893. [CrossRef]

3. Bieging, K.T.; Mello, S.S.; Attardi, L.D. Unravelling mechanisms of p53-mediated tumour suppression. Nat. Rev. Cancer 2014, 14, 359-370. [CrossRef] [PubMed]

4. Deng, C.; Zhang, P.; Harper, J.W.; Elledge, S.J.; Leder, P. Mice lacking p21CIP1/WAF1 undergo normal development, but are defective in G1 checkpoint control. Cell 1995, 82, 675-684. [CrossRef]

5. Hollander, M.C.; Sheikh, M.S.; Bulavin, D.V.; Lundgren, K.; Augeri-Henmueller, L.; Shehee, R.; Molinaro, T.A.; Kim, K.E.; Tolosa, E.; Ashwell, J.D.; et al. Genomic instability in Gadd45a-deficient mice. Nat. Genet. 1999, 23, 176-184. [CrossRef]

6. Fridman, J.S.; Lowe, S.W. Control of apoptosis by p53. Oncogene 2003, 22, 9030-9040. [CrossRef] [PubMed]

7. Rufini, A.; Tucci, P.; Celardo, I.; Melino, G. Senescence and aging: The critical roles of p53. Oncogene 2013, 32, 5129-5143. [CrossRef]

8. Green, D.R.; Kroemer, G. Cytoplasmic functions of the tumour suppressor p53. Nature 2009, 458, 1127-1130. [CrossRef]

9. Liang, S.H.; Clarke, M.F. Regulation of p53 localization. Eur. J. Biochem. 2001, 268, 2779-2783. [CrossRef]

10. Giorgi, C.; Bonora, M.; Sorrentino, G.; Missiroli, S.; Poletti, F.; Suski, J.M.; Galindo Ramirez, F.; Rizzuto, R.; Di Virgilio, F.; Zito, E.; et al. p53 at the endoplasmic reticulum regulates apoptosis in a Ca2+-dependent manner. Proc. Natl. Acad. Sci. USA 2015, 112, 1779-1784. [CrossRef]

11. Marchenko, N.D.; Zaika, A.; Moll, U.M. Death signal-induced localization of p53 protein to mitochondria. A potential role in apoptotic signaling. J. Biol. Chem. 2000, 275, 16202-16212. [CrossRef] [PubMed]

12. Mihara, M.; Erster, S.; Zaika, A.; Petrenko, O.; Chittenden, T.; Pancoska, P.; Moll, U.M. p53 has a direct apoptogenic role at the mitochondria. Mol. Cell 2003, 11, 577-590. [CrossRef]

13. Baugh, E.H.; Ke, H.; Levine, A.J.; Bonneau, R.A.; Chan, C.S. Why are there hotspot mutations in the TP53 gene in human cancers? Cell Death Differ. 2018, 25, 154-160. [CrossRef]

14. Parrales, A.; Iwakuma, T. Targeting Oncogenic Mutant p53 for Cancer Therapy. Front. Oncol. 2015, 5, 288. [CrossRef] [PubMed]

15. Walerych, D.; Lisek, K.; Del Sal, G. Mutant p53: One, No One, and One Hundred Thousand. Front. Oncol. 2015, 5, 289. [CrossRef]

16. Kim, M.P.; Zhang, Y.; Lozano, G. Mutant p53: Multiple Mechanisms Define Biologic Activity in Cancer. Front. Oncol. 2015, 5, 249. [CrossRef]

17. Lang, G.A.; Iwakuma, T.; Suh, Y.A.; Liu, G.; Rao, V.A.; Parant, J.M.; Valentin-Vega, Y.A.; Terzian, T.; Caldwell, L.C.; Strong, L.C.; et al. Gain of function of a p53 hot spot mutation in a mouse model of Li-Fraumeni syndrome. Cell 2004, 119, 861-872. [CrossRef]

18. Adorno, M.; Cordenonsi, M.; Montagner, M.; Dupont, S.; Wong, C.; Hann, B.; Solari, A.; Bobisse, S.; Rondina, M.B.; Guzzardo, V.; et al. A Mutant-p53/Smad complex opposes p63 to empower TGFbeta-induced metastasis. Cell 2009, 137, 87-98. [CrossRef]

19. Muller, P.A.; Caswell, P.T.; Doyle, B.; Iwanicki, M.P.; Tan, E.H.; Karim, S.; Lukashchuk, N.; Gillespie, D.A.; Ludwig, R.L.; Gosselin, P.; et al. Mutant p53 drives invasion by promoting integrin recycling. Cell 2009, 139, 1327-1341. [CrossRef]

20. Parrales, A.; Thoenen, E.; Iwakuma, T. The interplay between mutant p53 and the mevalonate pathway. Cell Death Differ. 2018, 25, 460-470. [CrossRef]

21. Yamamoto, S.; Iwakuma, T. Regulators of Oncogenic Mutant TP53 Gain of Function. Cancers 2018, 11, 4. [CrossRef] [PubMed]

22. Terzian, T.; Suh, Y.A.; Iwakuma, T.; Post, S.M.; Neumann, M.; Lang, G.A.; Van Pelt, C.S.; Lozano, G. The inherent instability of mutant p53 is alleviated by Mdm2 or p16INK4a loss. Genes Dev. 2008, 22, 1337-1344. [CrossRef]

23. Parrales, A.; Ranjan, A.; Iyer, S.V.; Padhye, S.; Weir, S.J.; Roy, A.; Iwakuma, T. DNAJA1 controls the fate of misfolded mutant p53 through the mevalonate pathway. Nat. Cell Biol. 2016, 18, 1233-1243. [CrossRef]

24. Tracz-Gaszewska, Z.; Klimczak, M.; Biecek, P.; Herok, M.; Kosinski, M.; Olszewski, M.B.; Czerwinska, P.; Wiech, M.; Wiznerowicz, M.; Zylicz, A.; et al. Molecular chaperones in the acquisition of cancer cell chemoresistance with mutated TP53 and MDM2 up-regulation. Oncotarget 2017, 8, 82123-82143. [CrossRef]

25. Wawrzynow, B.; Zylicz, A.; Zylicz, M. Chaperoning the guardian of the genome. The two-faced role of molecular chaperones in p53 tumor suppressor action. Biochim. Biophys. Acta (BBA) Rev. Cancer 2018, 1869, 161-174. [CrossRef] [PubMed]

26. Lukashchuk, N.; Vousden, K.H. Ubiquitination and degradation of mutant p53. Mol. Cell Biol. 2007, 27, 8284-8295. [CrossRef] [PubMed]

27. Jolly, C.; Morimoto, R.I. Role of the heat shock response and molecular chaperones in oncogenesis and cell death. J. Natl. Cancer Inst. 2000, 92, 1564-1572. [CrossRef]

28. Saibil, H. Chaperone machines for protein folding, unfolding and disaggregation. Nat. Rev. Mol. Cell Biol. $2013,14,630-642$. [CrossRef] [PubMed]

29. Doyle, S.M.; Genest, O.; Wickner, S. Protein rescue from aggregates by powerful molecular chaperone machines. Nat. Rev. Mol. Cell Biol. 2013, 14, 617-629. [CrossRef]

30. Hartl, F.U.; Bracher, A.; Hayer-Hartl, M. Molecular chaperones in protein folding and proteostasis. Nature 2011, 475, 324-332. [CrossRef] 
31. Rosenzweig, R.; Nillegoda, N.B.; Mayer, M.P.; Bukau, B. The Hsp70 chaperone network. Nat. Rev. Mol. Cell Biol. $2019,20,665-680$. [CrossRef]

32. Milarski, K.L.; Morimoto, R.I. Expression of human HSP70 during the synthetic phase of the cell cycle. Proc. Natl. Acad. Sci. USA 1986, 83, 9517-9521. [CrossRef] [PubMed]

33. Schmitt, E.; Parcellier, A.; Gurbuxani, S.; Cande, C.; Hammann, A.; Morales, M.C.; Hunt, C.R.; Dix, D.J.; Kroemer, R.T.; Giordanetto, F.; et al. Chemosensitization by a non-apoptogenic heat shock protein 70-binding apoptosis-inducing factor mutant. Cancer Res. 2003, 63, 8233-8240. [PubMed]

34. Aligue, R.; Akhavan-Niak, H.; Russell, P. A role for Hsp90 in cell cycle control: Wee1 tyrosine kinase activity requires interaction with Hsp90. EMBO J. 1994, 13, 6099-6106. [CrossRef] [PubMed]

35. Burrows, F.; Zhang, H.; Kamal, A. Hsp90 activation and cell cycle regulation. Cell Cycle 2004, 3, 1530-1536. [CrossRef]

36. Minami, Y.; Hohfeld, J.; Ohtsuka, K.; Hartl, F.U. Regulation of the heat-shock protein 70 reaction cycle by the mammalian DnaJ homolog, Hsp40. J. Biol. Chem. 1996, 271, 19617-19624. [CrossRef]

37. Kampinga, H.H.; Craig, E.A. The HSP70 chaperone machinery: J proteins as drivers of functional specificity. Nat. Rev. Mol. Cell Biol. 2010, 11, 579-592. [CrossRef]

38. Kityk, R.; Kopp, J.; Mayer, M.P. Molecular Mechanism of J-Domain-Triggered ATP Hydrolysis by Hsp70 Chaperones. Mol. Cell 2018, 69, 227-237.e224. [CrossRef]

39. Cyr, D.M. Cooperation of the molecular chaperone Ydj1 with specific Hsp70 homologs to suppress protein aggregation. FEBS Lett. 1995, 359, 129-132. [CrossRef]

40. Lu, Z.; Cyr, D.M. Protein folding activity of Hsp70 is modified differentially by the hsp40 co-chaperones Sis1 and Ydj1. J. Biol. Chem. 1998, 273, 27824-27830. [CrossRef] [PubMed]

41. Qi, M.; Zhang, J.; Zeng, W.; Chen, X. DNAJB1 stabilizes MDM2 and contributes to cancer cell proliferation in a p53-dependent manner. Biochim. Biophys. Acta 2014, 1839, 62-69. [CrossRef]

42. Hageman, J.; Rujano, M.A.; van Waarde, M.A.; Kakkar, V.; Dirks, R.P.; Govorukhina, N.; Oosterveld-Hut, H.M.; Lubsen, N.H.; Kampinga, H.H. A DNAJB chaperone subfamily with HDAC-dependent activities suppresses toxic protein aggregation. Mol. Cell 2010, 37, 355-369. [CrossRef]

43. Yang, C.; Owen, H.A.; Yang, P. Dimeric heat shock protein 40 binds radial spokes for generating coupled power strokes and recovery strokes of $9+2$ flagella. J. Cell Biol. 2008, 180, 403-415. [CrossRef] [PubMed]

44. Ushioda, R.; Hoseki, J.; Araki, K.; Jansen, G.; Thomas, D.Y.; Nagata, K. ERdj5 is required as a disulfide reductase for degradation of misfolded proteins in the ER. Science 2008, 321, 569-572. [CrossRef] [PubMed]

45. Sahi, C.; Lee, T.; Inada, M.; Pleiss, J.A.; Craig, E.A. Cwc23, an essential J protein critical for pre-mRNA splicing with a dispensable J domain. Mol. Cell Biol. 2010, 30, 33-42. [CrossRef]

46. Kim Chiaw, P.; Hantouche, C.; Wong, M.J.H.; Matthes, E.; Robert, R.; Hanrahan, J.W.; Shrier, A.; Young, J.C. Hsp70 and DNAJA2 limit CFTR levels through degradation. PLoS ONE 2019, 14, e0220984. [CrossRef] [PubMed]

47. Mok, S.A.; Condello, C.; Freilich, R.; Gillies, A.; Arhar, T.; Oroz, J.; Kadavath, H.; Julien, O.; Assimon, V.A.; Rauch, J.N.; et al. Mapping interactions with the chaperone network reveals factors that protect against tau aggregation. Nat. Struct. Mol. Biol. 2018, 25, 384-393. [CrossRef]

48. Baaklini, I.; Gonçalves, C.C.; Lukacs, G.L.; Young, J.C. Selective Binding of HSC70 and its Co-Chaperones to Structural Hotspots on CFTR. Sci. Rep. 2020, 10, 4176. [CrossRef]

49. Pohl, S.; Pervaiz, S.; Dharmarajan, A.; Agostino, M. Gene expression analysis of heat-shock proteins and redox regulators reveals combinatorial prognostic markers in carcinomas of the gastrointestinal tract. Redox Biol. 2019, 25, 101060. [CrossRef]

50. Mahoney, S.E.; Yao, Z.; Keyes, C.C.; Tapscott, S.J.; Diede, S.J. Genome-wide DNA methylation studies suggest distinct DNA methylation patterns in pediatric embryonal and alveolar rhabdomyosarcomas. Epigenetics 2012, 7, 400-408. [CrossRef]

51. Tukaj, S.; Kotlarz, A.; Jozwik, A.; Smolenska, Z.; Bryl, E.; Witkowski, J.M.; Lipinska, B. Hsp40 proteins modulate humoral and cellular immune response in rheumatoid arthritis patients. Cell Stress Chaperones 2010, 15, 555-566. [CrossRef]

52. Kotlarz, A.; Tukaj, S.; Krzewski, K.; Brycka, E.; Lipinska, B. Human Hsp40 proteins, DNAJA1 and DNAJA2, as potential targets of the immune response triggered by bacterial DnaJ in rheumatoid arthritis. Cell Stress Chaperones 2013, 18, 653-659. [CrossRef]

53. Wyttenbach, A.; Carmichael, J.; Swartz, J.; Furlong, R.A.; Narain, Y.; Rankin, J.; Rubinsztein, D.C. Effects of heat shock, heat shock protein 40 (HDJ-2), and proteasome inhibition on protein aggregation in cellular models of Huntington's disease. Proc. Natl. Acad. Sci. USA 2000, 97, 2898-2903. [CrossRef]

54. Rodríguez-González, C.; Lin, S.; Arkan, S.; Hansen, C. Co-chaperones DNAJA1 and DNAJB6 are critical for regulation of polyglutamine aggregation. Sci. Rep. 2020, 10, 8130. [CrossRef]

55. Xu, D.; Tong, X.; Sun, L.; Li, H.; Jones, R.D.; Liao, J.; Yang, G.Y. Inhibition of mutant Kras and p53-driven pancreatic carcinogenesis by atorvastatin: Mainly via targeting of the farnesylated DNAJA1 in chaperoning mutant p53. Mol. Carcinog. 2019, 58, $2052-2064$. [CrossRef] [PubMed]

56. Yang, S.; Ren, X.; Liang, Y.; Yan, Y.; Zhou, Y.; Hu, J.; Wang, Z.; Song, F.; Wang, F.; Liao, W.; et al. KNK437 restricts the growth and metastasis of colorectal cancer via targeting DNAJA1/CDC45 axis. Oncogene 2020, 39, 249-261. [CrossRef]

57. Stark, J.L.; Mehla, K.; Chaika, N.; Acton, T.B.; Xiao, R.; Singh, P.K.; Montelione, G.T.; Powers, R. Structure and function of human DnaJ homologue subfamily a member 1 (DNAJA1) and its relationship to pancreatic cancer. Biochemistry 2014, 53, 1360-1372. [CrossRef] 
58. Chung, Y.T.; Matkowskyj, K.A.; Li, H.; Bai, H.; Zhang, W.; Tsao, M.S.; Liao, J.; Yang, G.Y. Overexpression and oncogenic function of aldo-keto reductase family 1B10 (AKR1B10) in pancreatic carcinoma. Mod. Pathol. 2012, 25, 758-766. [CrossRef] [PubMed]

59. Meshalkina, D.A.; Shevtsov, M.A.; Dobrodumov, A.V.; Komarova, E.Y.; Voronkina, I.V.; Lazarev, V.F.; Margulis, B.A.; Guzhova, I.V. Knock-down of Hdj2/DNAJA1 co-chaperone results in an unexpected burst of tumorigenicity of C6 glioblastoma cells. Oncotarget 2016, 7, 22050-22063. [CrossRef] [PubMed]

60. Ileri, F.C.; Acun, T. High expression of DNAJA1 (HDJ2) predicts unfavorable survival outcomes in breast cancer. Biomark. Med. 2021, 15, 941-950. [CrossRef]

61. Roth, H.E.; Bhinderwala, F.; Franco, R.; Zhou, Y.; Powers, R. DNAJA1 Dysregulates Metabolism Promoting an Antiapoptotic Phenotype in Pancreatic Ductal Adenocarcinoma. J. Proteome Res. 2021, 20, 3925-3939. [CrossRef] [PubMed]

62. Ergulen, E.; Becsi, B.; Csomos, I.; Fesus, L.; Kanchan, K. Identification of DNAJA1 as a novel interacting partner and a substrate of human transglutaminase 2. Biochem. J. 2016, 473, 3889-3901. [CrossRef] [PubMed]

63. Gotoh, T.; Terada, K.; Oyadomari, S.; Mori, M. hsp70-DnaJ chaperone pair prevents nitric oxide- and CHOP-induced apoptosis by inhibiting translocation of Bax to mitochondria. Cell Death Differ. 2004, 11, 390-402. [CrossRef]

64. Tong, X.; Xu, D.; Mishra, R.K.; Jones, R.D.; Sun, L.; Schiltz, G.E.; Liao, J.; Yang, G.Y. Identification of a druggable protein-protein interaction site between mutant p53 and its stabilizing chaperone DNAJA1. J. Biol. Chem. 2020, 296, 100098. [CrossRef] [PubMed]

65. Kaida, A.; Yamamoto, S.; Parrales, A.; Young, E.D.; Ranjan, A.; Alalem, M.A.; Morita, K.I.; Oikawa, Y.; Harada, H.; Ikeda, T.; et al. DNAJA1 promotes cancer metastasis through interaction with mutant p53. Oncogene 2021, 40, 5013-5025. [CrossRef]

66. Terada, K.; Mori, M. Human DnaJ homologs dj2 and dj3, and bag-1 are positive cochaperones of hsc70. J. Biol. Chem. 2000, 275, 24728-24734. [CrossRef] [PubMed]

67. Wang, C.C.; Liao, Y.P.; Mischel, P.S.; Iwamoto, K.S.; Cacalano, N.A.; McBride, W.H. HDJ-2 as a target for radiosensitization of glioblastoma multiforme cells by the farnesyltransferase inhibitor R115777 and the role of the p53/p21 pathway. Cancer Res. 2006, 66, 6756-6762. [CrossRef] [PubMed]

68. Ahn, B.Y.; Trinh, D.L.; Zajchowski, L.D.; Lee, B.; Elwi, A.N.; Kim, S.W. Tid1 is a new regulator of p53 mitochondrial translocation and apoptosis in cancer. Oncogene 2010, 29, 1155-1166. [CrossRef]

69. Trinh, D.L.; Elwi, A.N.; Kim, S.W. Direct interaction between p53 and Tid1 proteins affects p53 mitochondrial localization and apoptosis. Oncotarget 2010, 1, 396-404. [CrossRef]

70. Cui, X.; Choi, H.K.; Choi, Y.S.; Park, S.Y.; Sung, G.J.; Lee, Y.H.; Lee, J.; Jun, W.J.; Kim, K.; Choi, K.C.; et al. DNAJB1 destabilizes PDCD5 to suppress p53-mediated apoptosis. Cancer Lett. 2015, 357, 307-315. [CrossRef]

71. Hiraki, M.; Hwang, S.Y.; Cao, S.; Ramadhar, T.R.; Byun, S.; Yoon, K.W.; Lee, J.H.; Chu, K.; Gurkar, A.U.; Kolev, V.; et al. Small-Molecule Reactivation of Mutant p53 to Wild-Type-like p53 through the p53-Hsp40 Regulatory Axis. Chem. Biol. 2015, 22, 1206-1216. [CrossRef] [PubMed]

72. Lee, H.J.; Kim, J.M.; Kim, K.H.; Heo, J.I.; Kwak, S.J.; Han, J.A. Genotoxic stress/p53-induced DNAJB9 inhibits the pro-apoptotic function of p53. Cell Death Differ. 2015, 22, 86-95. [CrossRef]

73. Lee, H.J.; Jung, Y.J.; Lee, S.; Kim, J.I.; Han, J.A. DNAJB9 Inhibits p53-Dependent Oncogene-Induced Senescence and Induces Cell Transformation. Mol. Cells 2020, 43, 397-407. [CrossRef] [PubMed]

74. Lazare, C.; Zhi, W.; Dai, J.; Cao, C.; Sookha, R.R.; Wang, L.; Meng, Y.; Gao, P.; Wu, P.; Wei, J.; et al. A pilot study comparing the genetic molecular biology of gestational and non-gestational choriocarcinoma. Am. J. Transl. Res. 2019, 11, 7049-7062.

75. Imamura, T.; Komatsu, S.; Ichikawa, D.; Miyamae, M.; Okajima, W.; Ohashi, T.; Kiuchi, J.; Nishibeppu, K.; Kosuga, T.; Konishi, H.; et al. Overexpression of ZRF1 is related to tumor malignant potential and a poor outcome of gastric carcinoma. Carcinogenesis 2018, 39, 263-271. [CrossRef]

76. Kubo, N.; Wu, D.; Yoshihara, Y.; Sang, M.; Nakagawara, A.; Ozaki, T. Co-chaperon DnaJC7/TPR2 enhances p53 stability and activity through blocking the complex formation between p53 and MDM2. Biochem. Biophys. Res. Commun. 2013, 430, 1034-1039. [CrossRef]

77. Tebaldi, T.; Zaccara, S.; Alessandrini, F.; Bisio, A.; Ciribilli, Y.; Inga, A. Whole-genome cartography of p53 response elements ranked on transactivation potential. BMC Genom. 2015, 16, 464. [CrossRef] [PubMed]

78. Isermann, T.; Sener, O.C.; Stender, A.; Klemke, L.; Winkler, N.; Neesse, A.; Li, J.; Wegwitz, F.; Moll, U.M.; Schulz-Heddergott, R. Suppression of HSF1 activity by wildtype p53 creates a driving force for p53 loss-of-heterozygosity. Nat. Commun. 2021, 12, 4019. [CrossRef] [PubMed]

79. Nitika; Blackman, J.S.; Knighton, L.E.; Takakuwa, J.E.; Calderwood, S.K.; Truman, A.W. Chemogenomic screening identifies the Hsp70 co-chaperone DNAJA1 as a hub for anticancer drug resistance. Sci. Rep. 2020, 10, 13831. [CrossRef]

80. Masunaga, S.; Ono, K.; Takahashi, A.; Ohnishi, T.; Kinashi, Y.; Takagaki, M. Radiobiological characteristics of solid tumours depending on the p53 status of the tumour cells, with emphasis on the response of intratumour quiescent cells. Eur. J. Cancer 2002, 38, 718-727. [CrossRef]

81. Masunaga, S.I.; Kobayashi, J.; Tano, K.; Sanada, Y.; Suzuki, M.; Ono, K. The Effect of p53 Status on Radio-Sensitivity of Quiescent Tumor Cell Population Irradiated With $\gamma$-Rays at Various Dose Rates. J. Clin. Med. Res. 2018, 10, 815-821. [CrossRef] [PubMed]

82. Okaichi, K.; Ide-Kanematsu, M.; Izumi, N.; Morita, N.; Okumura, Y.; Ihara, M. Variations in sensitivity to ionizing radiation in relation to p53 mutation point. Anticancer Res. 2008, 28, 2687-2690. 
83. Skinner, H.D.; Sandulache, V.C.; Ow, T.J.; Meyn, R.E.; Yordy, J.S.; Beadle, B.M.; Fitzgerald, A.L.; Giri, U.; Ang, K.K.; Myers, J.N. TP53 disruptive mutations lead to head and neck cancer treatment failure through inhibition of radiation-induced senescence. Clin. Cancer Res. 2012, 18, 290-300. [CrossRef] [PubMed]

84. Wisén, S.; Bertelsen, E.B.; Thompson, A.D.; Patury, S.; Ung, P.; Chang, L.; Evans, C.G.; Walter, G.M.; Wipf, P.; Carlson, H.A.; et al. Binding of a small molecule at a protein-protein interface regulates the chaperone activity of hsp70-hsp40. ACS Chem. Biol. 2010, 5, 611-622. [CrossRef] [PubMed]

85. Moses, M.A.; Kim, Y.S.; Rivera-Marquez, G.M.; Oshima, N.; Watson, M.J.; Beebe, K.E.; Wells, C.; Lee, S.; Zuehlke, A.D.; Shao, H.; et al. Targeting the Hsp40/Hsp70 Chaperone Axis as a Novel Strategy to Treat Castration-Resistant Prostate Cancer. Cancer Res. 2018, 78, 4022-4035. [CrossRef] [PubMed]

86. Wang, S.F.; Huang, K.H.; Tseng, W.C.; Lo, J.F.; Li, A.F.; Fang, W.L.; Chen, C.F.; Yeh, T.S.; Chang, Y.L.; Chou, Y.C.; et al. DNAJA3/Tid1 Is Required for Mitochondrial DNA Maintenance and Regulates Migration and Invasion of Human Gastric Cancer Cells. Cancers 2020, 12, 3463. [CrossRef] [PubMed]

87. Syken, J.; De-Medina, T.; Munger, K. TID1, a human homolog of the Drosophila tumor suppressor 1(2)tid, encodes two mitochondrial modulators of apoptosis with opposing functions. Proc. Natl. Acad. Sci. USA 1999, 96, 8499-8504. [CrossRef]

88. Chen, C.Y.; Chiou, S.H.; Huang, C.Y.; Jan, C.I.; Lin, S.C.; Hu, W.Y.; Chou, S.H.; Liu, C.J.; Lo, J.F. Tid1 functions as a tumour suppressor in head and neck squamous cell carcinoma. J. Pathol. 2009, 219, 347-355. [CrossRef] [PubMed]

89. Tarunina, M.; Alger, L.; Chu, G.; Munger, K.; Gudkov, A.; Jat, P.S. Functional genetic screen for genes involved in senescence: Role of Tid1, a homologue of the Drosophila tumor suppressor 1(2)tid, in senescence and cell survival. Mol. Cell Biol. 2004, 24, 10792-10801. [CrossRef]

90. Cheng, L.H.; Hung, K.F.; Lee, T.C.; Huang, C.Y.; Chiu, W.T.; Lo, J.F.; Huang, T.F. Mitochondrial co-chaperone protein Tid1 is required for energy homeostasis during skeletal myogenesis. Stem. Cell Res. Ther. 2016, 7, 185. [CrossRef]

91. Lu, B.; Garrido, N.; Spelbrink, J.N.; Suzuki, C.K. Tid1 isoforms are mitochondrial DnaJ-like chaperones with unique carboxyl termini that determine cytosolic fate. J. Biol. Chem. 2006, 281, 13150-13158. [CrossRef]

92. Maletzko, A.; Key, J.; Wittig, I.; Gispert, S.; Koepf, G.; Canet-Pons, J.; Torres-Odio, S.; West, A.P.; Auburger, G. Increased presence of nuclear DNAJA3 and upregulation of cytosolic STAT1 and of nucleic acid sensors trigger innate immunity in the ClpP-null mouse. Neurogenetics 2021, 22, 297-312. [CrossRef]

93. Schilling, B.; De-Medina, T.; Syken, J.; Vidal, M.; Münger, K. A novel human DnaJ protein, hTid-1, a homolog of the Drosophila tumor suppressor protein Tid56, can interact with the human papillomavirus type 16 E7 oncoprotein. Virology 1998, $247,74-85$. [CrossRef] [PubMed]

94. Cheng, H.; Cenciarelli, C.; Shao, Z.; Vidal, M.; Parks, W.P.; Pagano, M.; Cheng-Mayer, C. Human T cell leukemia virus type 1 Tax associates with a molecular chaperone complex containing hTid-1 and Hsp70. Curr. Biol. 2001, 11, 1771-1775. [CrossRef]

95. Cheng, H.; Cenciarelli, C.; Tao, M.; Parks, W.P.; Cheng-Mayer, C. HTLV-1 Tax-associated hTid-1, a human DnaJ protein, is a repressor of Ikappa B kinase beta subunit. J. Biol. Chem. 2002, 277, 20605-20610. [CrossRef] [PubMed]

96. Zhang, W.; Yang, F.; Zhu, Z.; Yang, Y.; Wang, Z.; Cao, W.; Dang, W.; Li, L.; Mao, R.; Liu, Y.; et al. Cellular DNAJA3, a Novel VP1-Interacting Protein, Inhibits Foot-and-Mouth Disease Virus Replication by Inducing Lysosomal Degradation of VP1 and Attenuating Its Antagonistic Role in the Beta Interferon Signaling Pathway. J. Virol. 2019, 93, e00588-19. [CrossRef]

97. Hayashi, M.; Imanaka-Yoshida, K.; Yoshida, T.; Wood, M.; Fearns, C.; Tatake, R.J.; Lee, J.D. A crucial role of mitochondrial Hsp40 in preventing dilated cardiomyopathy. Nat. Med. 2006, 12, 128-132. [CrossRef]

98. Chen, Y.S.; Chang, C.W.; Tsay, Y.G.; Huang, L.Y.; Wu, Y.C.; Cheng, L.H.; Yang, C.C.; Wu, C.H.; Teo, W.H.; Hung, K.F.; et al. HSP40 co-chaperone protein Tid1 suppresses metastasis of head and neck cancer by inhibiting Galectin-7-TCF3-MMP9 axis signaling. Theranostics 2018, 8, 3841-3855. [CrossRef]

99. Jan, C.I.; Yu, C.C.; Hung, M.C.; Harn, H.J.; Nieh, S.; Lee, H.S.; Lou, M.A.; Wu, Y.C.; Chen, C.Y.; Huang, C.Y.; et al. Tid1, CHIP and ErbB2 interactions and their prognostic implications for breast cancer patients. J. Pathol. 2011, 225, 424-437. [CrossRef] [PubMed]

100. Chen, C.Y.; Jan, C.I.; Lo, J.F.; Yang, S.C.; Chang, Y.L.; Pan, S.H.; Wang, W.L.; Hong, T.M.; Yang, P.C. Tid1-L inhibits EGFR signaling in lung adenocarcinoma by enhancing EGFR Ubiquitinylation and degradation. Cancer Res. 2013, 73, 4009-4019. [CrossRef]

101. Chen, K.Y.; Huang, Y.H.; Teo, W.H.; Chang, C.W.; Chen, Y.S.; Yeh, Y.C.; Lee, C.J.; Lo, J.F. Loss of Tid1/DNAJA3 Co-Chaperone Promotes Progression and Recurrence of Hepatocellular Carcinoma after Surgical Resection: A Novel Model to Stratify Risk of Recurrence. Cancers 2021, 13, 138. [CrossRef]

102. Bae, M.K.; Jeong, J.W.; Kim, S.H.; Kim, S.Y.; Kang, H.J.; Kim, D.M.; Bae, S.K.; Yun, I.; Trentin, G.A.; Rozakis-Adcock, M.; et al. Tid-1 interacts with the von Hippel-Lindau protein and modulates angiogenesis by destabilization of HIF-1alpha. Cancer Res. 2005, 65, 2520-2525. [CrossRef]

103. Kurzik-Dumke, U.; Horner, M.; Czaja, J.; Nicotra, M.R.; Simiantonaki, N.; Koslowski, M.; Natali, P.G. Progression of colorectal cancers correlates with overexpression and loss of polarization of expression of the htid-1 tumor suppressor. Int. J. Mol. Med. 2008, 21, 19-31. [CrossRef] [PubMed]

104. Wang, T.H.; Lin, Y.H.; Yang, S.C.; Chang, P.C.; Wang, T.C.; Chen, C.Y. Tid1-S regulates the mitochondrial localization of EGFR in non-small cell lung carcinoma. Oncogenesis 2017, 6, e361. [CrossRef]

105. Faust, O.; Abayev-Avraham, M.; Wentink, A.S.; Maurer, M.; Nillegoda, N.B.; London, N.; Bukau, B.; Rosenzweig, R. HSP40 proteins use class-specific regulation to drive HSP70 functional diversity. Nature 2020, 587, 489-494. [CrossRef] 
106. Gess, B.; Auer-Grumbach, M.; Schirmacher, A.; Strom, T.; Zitzelsberger, M.; Rudnik-Schöneborn, S.; Röhr, D.; Halfter, H.; Young, P.; Senderek, J. HSJ1-related hereditary neuropathies: Novel mutations and extended clinical spectrum. Neurology 2014, 83, 1726-1732. [CrossRef] [PubMed]

107. Lupo, V.; García-García, F.; Sancho, P.; Tello, C.; García-Romero, M.; Villarreal, L.; Alberti, A.; Sivera, R.; Dopazo, J.; PascualPascual, S.I.; et al. Assessment of Targeted Next-Generation Sequencing as a Tool for the Diagnosis of Charcot-Marie-Tooth Disease and Hereditary Motor Neuropathy. J. Mol. Diagn 2016, 18, 225-234. [CrossRef]

108. Sanchez, E.; Darvish, H.; Mesias, R.; Taghavi, S.; Firouzabadi, S.G.; Walker, R.H.; Tafakhori, A.; Paisán-Ruiz, C. Identification of a Large DNAJB2 Deletion in a Family with Spinal Muscular Atrophy and Parkinsonism. Hum. Mutat. 2016, 37, 1180-1189. [CrossRef] [PubMed]

109. Sato, T.; Hayashi, Y.K.; Oya, Y.; Kondo, T.; Sugie, K.; Kaneda, D.; Houzen, H.; Yabe, I.; Sasaki, H.; Noguchi, S.; et al. DNAJB6 myopathy in an Asian cohort and cytoplasmic/nuclear inclusions. Neuromuscul. Disord. 2013, 23, 269-276. [CrossRef]

110. Harms, M.B.; Sommerville, R.B.; Allred, P.; Bell, S.; Ma, D.; Cooper, P.; Lopate, G.; Pestronk, A.; Weihl, C.C.; Baloh, R.H. Exome sequencing reveals DNAJB6 mutations in dominantly-inherited myopathy. Ann. Neurol. 2012, 71, 407-416. [CrossRef]

111. Sarparanta, J.; Jonson, P.H.; Golzio, C.; Sandell, S.; Luque, H.; Screen, M.; McDonald, K.; Stajich, J.M.; Mahjneh, I.; Vihola, A.; et al. Mutations affecting the cytoplasmic functions of the co-chaperone DNAJB6 cause limb-girdle muscular dystrophy. Nat. Genet. 2012, 44, s451-452. [CrossRef] [PubMed]

112. Palmio, J.; Jonson, P.H.; Evilä, A.; Auranen, M.; Straub, V.; Bushby, K.; Sarkozy, A.; Kiuru-Enari, S.; Sandell, S.; Pihko, H.; et al. Novel mutations in DNAJB6 gene cause a very severe early-onset limb-girdle muscular dystrophy 1D disease. Neuromuscul. Disord. 2015, 25, 835-842. [CrossRef]

113. Tsai, P.C.; Tsai, Y.S.; Soong, B.W.; Huang, Y.H.; Wu, H.T.; Chen, Y.H.; Lin, K.P.; Liao, Y.C.; Lee, Y.C. A novel DNAJB6 mutation causes dominantly inherited distal-onset myopathy and compromises DNAJB6 function. Neuromuscul. Disord. 2017, 92, 150-157. [CrossRef]

114. El Khouri, E.; Thomas, L.; Jeanson, L.; Bequignon, E.; Vallette, B.; Duquesnoy, P.; Montantin, G.; Copin, B.; Dastot-Le Moal, F.; Blanchon, S.; et al. Mutations in DNAJB13, Encoding an HSP40 Family Member, Cause Primary Ciliary Dyskinesia and Male Infertility. Am. J. Hum. Genet. 2016, 99, 489-500. [CrossRef] [PubMed]

115. Honeyman, J.N.; Simon, E.P.; Robine, N.; Chiaroni-Clarke, R.; Darcy, D.G.; Lim, I.; Gleason, C.E.; Murphy, J.M.; Rosenberg, B.R.; Teegan, L.; et al. Detection of a recurrent DNAJB1-PRKACA chimeric transcript in fibrolamellar hepatocellular carcinoma. Science 2014, 343, 1010-1014. [CrossRef]

116. Chen, C.H.; Chang, W.H.; Su, K.Y.; Ku, W.H.; Chang, G.C.; Hong, Q.S.; Hsiao, Y.J.; Chen, H.C.; Chen, H.Y.; Wu, R.; et al. HLJ1 is an endogenous Src inhibitor suppressing cancer progression through dual mechanisms. Oncogene 2016, 35, 5674-5685. [CrossRef] [PubMed]

117. Miao, W.; Li, L.; Wang, Y. A Targeted Proteomic Approach for Heat Shock Proteins Reveals DNAJB4 as a Suppressor for Melanoma Metastasis. Anal. Chem. 2018, 90, 6835-6842. [CrossRef] [PubMed]

118. Uretmen Kagiali, Z.C.; Sanal, E.; Karayel, O.; Polat, A.N.; Saatci, O.; Ersan, P.G.; Trappe, K.; Renard, B.Y.; Onder, T.T.; Tuncbag, N.; et al. Systems-level Analysis Reveals Multiple Modulators of Epithelial-mesenchymal Transition and Identifies DNAJB4 and CD81 as Novel Metastasis Inducers in Breast Cancer. Mol. Cell Proteom. 2019, 18, 1756-1771. [CrossRef] [PubMed]

119. Menezes, M.E.; Mitra, A.; Shevde, L.A.; Samant, R.S. DNAJB6 governs a novel regulatory loop determining Wnt/beta-catenin signalling activity. Biochem. J. 2012, 444, 573-580. [CrossRef]

120. Mitra, A.; Fillmore, R.A.; Metge, B.J.; Rajesh, M.; Xi, Y.; King, J.; Ju, J.; Pannell, L.; Shevde, L.A.; Samant, R.S. Large isoform of MRJ (DNAJB6) reduces malignant activity of breast cancer. Breast Cancer Res. 2008, 10, R22. [CrossRef]

121. Tien, J.F.; Mazloomian, A.; Cheng, S.G.; Hughes, C.S.; Chow, C.C.T.; Canapi, L.T.; Oloumi, A.; Trigo-Gonzalez, G.; Bashashati, A.; $\mathrm{Xu}$, J.; et al. CDK12 regulates alternative last exon mRNA splicing and promotes breast cancer cell invasion. Nucleic Acids Res. 2017, 45, 6698-6716. [CrossRef] [PubMed]

122. Yu, V.Z.; Wong, V.C.; Dai, W.; Ko, J.M.; Lam, A.K.; Chan, K.W.; Samant, R.S.; Lung, H.L.; Shuen, W.H.; Law, S.; et al. Nuclear Localization of DNAJB6 Is Associated With Survival of Patients With Esophageal Cancer and Reduces AKT Signaling and Proliferation of Cancer Cells. Gastroenterology 2015, 149, 1825-1836.e1825. [CrossRef]

123. Zhang, T.T.; Jiang, Y.Y.; Shang, L.; Shi, Z.Z.; Liang, J.W.; Wang, Z.; Zhang, Y.; Hao, J.J.; Jia, X.M.; Xu, X.; et al. Overexpression of DNAJB6 promotes colorectal cancer cell invasion through an IQGAP1/ERK-dependent signaling pathway. Mol. Carcinog. 2015, 54, 1205-1213. [CrossRef]

124. Nishizawa, S.; Hirohashi, Y.; Torigoe, T.; Takahashi, A.; Tamura, Y.; Mori, T.; Kanaseki, T.; Kamiguchi, K.; Asanuma, H.; Morita, R.; et al. HSP DNAJB8 controls tumor-initiating ability in renal cancer stem-like cells. Cancer Res. 2012, 72, $2844-2854$. [CrossRef] [PubMed]

125. Kusumoto, H.; Hirohashi, Y.; Nishizawa, S.; Yamashita, M.; Yasuda, K.; Murai, A.; Takaya, A.; Mori, T.; Kubo, T.; Nakatsugawa, M.; et al. Cellular stress induces cancer stem-like cells through expression of DNAJB8 by activation of heat shock factor 1. Cancer Sci. 2018, 109, 741-750. [CrossRef]

126. Pan, J.; Cao, D.; Gong, J. The endoplasmic reticulum co-chaperone ERdj3/DNAJB11 promotes hepatocellular carcinoma progression through suppressing AATZ degradation. Future Oncol. 2018, 14, 3001-3013. [CrossRef] [PubMed]

127. Sopha, P.; Ren, H.Y.; Grove, D.E.; Cyr, D.M. Endoplasmic reticulum stress-induced degradation of DNAJB12 stimulates BOK accumulation and primes cancer cells for apoptosis. J. Biol. Chem. 2017, 292, 11792-11803. [CrossRef] 
128. Gao, X.; Carroni, M.; Nussbaum-Krammer, C.; Mogk, A.; Nillegoda, N.B.; Szlachcic, A.; Guilbride, D.L.; Saibil, H.R.; Mayer, M.P.; Bukau, B. Human Hsp70 Disaggregase Reverses Parkinson's-Linked alpha-Synuclein Amyloid Fibrils. Mol. Cell 2015, 59, 781-793. [CrossRef]

129. Irwin, R.; Faust, O.; Petrovic, I.; Wolf, S.G.; Hofmann, H.; Rosenzweig, R. Hsp40s play complementary roles in the prevention of tau amyloid formation. Elife 2021, 10, e69601. [CrossRef]

130. Takashima, K.; Oshiumi, H.; Matsumoto, M.; Seya, T. DNAJB1/HSP40 Suppresses Melanoma Differentiation-Associated Gene 5-Mitochondrial Antiviral Signaling Protein Function in Conjunction with HSP70. J. Innate Immun. 2018, 10, 44-55. [CrossRef]

131. Batra, J.; Tripathi, S.; Kumar, A.; Katz, J.M.; Cox, N.J.; Lal, R.B.; Sambhara, S.; Lal, S.K. Human Heat shock protein 40 (Hsp40/DnaJB1) promotes influenza A virus replication by assisting nuclear import of viral ribonucleoproteins. Sci. Rep. 2016, 6, 19063. [CrossRef]

132. Park, S.Y.; Choi, H.K.; Seo, J.S.; Yoo, J.Y.; Jeong, J.W.; Choi, Y.; Choi, K.C.; Yoon, H.G. DNAJB1 negatively regulates MIG6 to promote epidermal growth factor receptor signaling. Biochim. Biophys. Acta 2015, 1853, 2722-2730. [CrossRef]

133. Kastenhuber, E.R.; Lalazar, G.; Houlihan, S.L.; Tschaharganeh, D.F.; Baslan, T.; Chen, C.C.; Requena, D.; Tian, S.; Bosbach, B.; Wilkinson, J.E.; et al. DNAJB1-PRKACA fusion kinase interacts with beta-catenin and the liver regenerative response to drive fibrolamellar hepatocellular carcinoma. Proc. Natl. Acad. Sci. USA 2017, 114, 13076-13084. [CrossRef]

134. Hackel, P.O.; Gishizky, M.; Ullrich, A. Mig-6 is a negative regulator of the epidermal growth factor receptor signal. Biol. Chem. 2001, 382, 1649-1662. [CrossRef] [PubMed]

135. Ren, H.; Luo, M.; Chen, J.; Zhou, Y.; Li, X.; Zhan, Y.; Shen, D.; Chen, B. Identification of TPD52 and DNAJB1 as two novel bile biomarkers for cholangiocarcinoma by iTRAQbased quantitative proteomics analysis. Oncol. Rep. 2019, 42, 2622-2634. [CrossRef] [PubMed]

136. King, F.W.; Wawrzynow, A.; Hohfeld, J.; Zylicz, M. Co-chaperones Bag-1, Hop and Hsp40 regulate Hsc70 and Hsp90 interactions with wild-type or mutant p53. EMBO J. 2001, 20, 6297-6305. [CrossRef] [PubMed]

137. Sugito, K.; Yamane, M.; Hattori, H.; Hayashi, Y.; Tohnai, I.; Ueda, M.; Tsuchida, N.; Ohtsuka, K. Interaction between hsp70 and hsp40, eukaryotic homologues of DnaK and DnaJ, in human cells expressing mutant-type p53. FEBS Lett. 1995, 358, 161-164. [CrossRef]

138. Silva, G.; Marins, M.; Chaichanasak, N.; Yoon, Y.; Fachin, A.L.; Pinhanelli, V.C.; Regasini, L.O.; Dos Santos, M.B.; Ayusso, G.M.; Marques, B.C.; et al. Trans-chalcone increases p53 activity via DNAJB1/HSP40 induction and CRM1 inhibition. PLoS ONE 2018, 13, e0202263. [CrossRef] [PubMed]

139. Shen, Y.; Meunier, L.; Hendershot, L.M. Identification and characterization of a novel endoplasmic reticulum (ER) DnaJ homologue, which stimulates ATPase activity of BiP in vitro and is induced by ER stress. J. Biol. Chem. 2002, 277, 15947-15956. [CrossRef]

140. Kurisu, J.; Honma, A.; Miyajima, H.; Kondo, S.; Okumura, M.; Imaizumi, K. MDG1/ERdj4, an ER-resident DnaJ family member, suppresses cell death induced by ER stress. Genes Cells 2003, 8, 189-202. [CrossRef] [PubMed]

141. Dong, M.; Bridges, J.P.; Apsley, K.; Xu, Y.; Weaver, T.E. ERdj4 and ERdj5 are required for endoplasmic reticulum-associated protein degradation of misfolded surfactant protein C. Mol. Biol. Cell 2008, 19, 2620-2630. [CrossRef]

142. Huang, Y.; Arora, K.; Mun, K.S.; Yang, F.; Moon, C.; Yarlagadda, S.; Jegga, A.; Weaver, T.; Naren, A.P. Targeting DNAJB9, a novel ER luminal co-chaperone, to rescue $\triangle$ F508-CFTR. Sci. Rep. 2019, 9, 9808. [CrossRef] [PubMed]

143. Sun, F.; Liao, Y.; Qu, X.; Xiao, X.; Hou, S.; Chen, Z.; Huang, H.; Li, P.; Fu, S. Hepatic DNAJB9 Drives Anabolic Biasing to Reduce Steatosis and Obesity. Cell Rep. 2020, 30, 1835-1847.e1839. [CrossRef] [PubMed]

144. Kim, H.Y.; Kim, Y.M.; Hong, S. DNAJB9 suppresses the metastasis of triple-negative breast cancer by promoting FBXO45-mediated degradation of ZEB1. Cell Death Dis. 2021, 12, 461. [CrossRef]

145. Lei, J.X.; Cassone, C.G.; Luebbert, C.; Liu, Q.Y. A novel neuron-enriched protein SDIM1 is down regulated in Alzheimer's brains and attenuates cell death induced by DNAJB4 over-expression in neuro-progenitor cells. Mol. Neurodegener. 2011, 6, 9. [CrossRef]

146. Snider, J.C.; Riley, L.A.; Mallory, N.T.; Bersi, M.R.; Umbarkar, P.; Gautam, R.; Zhang, Q.; Mahadevan-Jansen, A.; Hatzopoulos, A.K.; Maroteaux, L.; et al. Targeting 5-HT(2B) Receptor Signaling Prevents Border Zone Expansion and Improves Microstructural Remodeling After Myocardial Infarction. Circulation 2021, 143, 1317-1330. [CrossRef]

147. Tsai, M.F.; Wang, C.C.; Chang, G.C.; Chen, C.Y.; Chen, H.Y.; Cheng, C.L.; Yang, Y.P.; Wu, C.Y.; Shih, F.Y.; Liu, C.C.; et al. A new tumor suppressor DnaJ-like heat shock protein, HLJ1, and survival of patients with non-small-cell lung carcinoma. J. Natl. Cancer Inst. 2006, 98, 825-838. [CrossRef]

148. Liu, Y.; Zhou, J.; Zhang, C.; Fu, W.; Xiao, X.; Ruan, S.; Zhang, Y.; Luo, X.; Tang, M. HLJ1 is a novel biomarker for colorectal carcinoma progression and overall patient survival. Int. J. Clin. Exp. Pathol. 2014, 7, 969-977. [PubMed]

149. Acun, T.; Doberstein, N.; Habermann, J.K.; Gemoll, T.; Thorns, C.; Oztas, E.; Ried, T. HLJ1 (DNAJB4) Gene Is a Novel Biomarker Candidate in Breast Cancer. OMICS 2017, 21, 257-265. [CrossRef] [PubMed]

150. Lin, Y.; Peng, N.; Zhuang, H.; Zhang, D.; Wang, Y.; Hua, Z.C. Heat shock proteins HSP70 and MRJ cooperatively regulate cell adhesion and migration through urokinase receptor. BMC Cancer 2014, 14, 639. [CrossRef] [PubMed]

151. Mitra, A.; Menezes, M.E.; Shevde, L.A.; Samant, R.S. DNAJB6 induces degradation of beta-catenin and causes partial reversal of mesenchymal phenotype. J. Biol. Chem. 2010, 285, 24686-24694. [CrossRef] [PubMed]

152. Mitra, A.; Menezes, M.E.; Pannell, L.K.; Mulekar, M.S.; Honkanen, R.E.; Shevde, L.A.; Samant, R.S. DNAJB6 chaperones PP2A mediated dephosphorylation of GSK3beta to downregulate beta-catenin transcription target, osteopontin. Oncogene 2012, 31, 4472-4483. [CrossRef] [PubMed] 
153. Gillis, J.; Schipper-Krom, S.; Juenemann, K.; Gruber, A.; Coolen, S.; van den Nieuwendijk, R.; van Veen, H.; Overkleeft, H.; Goedhart, J.; Kampinga, H.H.; et al. The DNAJB6 and DNAJB8 protein chaperones prevent intracellular aggregation of polyglutamine peptides. J. Biol. Chem. 2013, 288, 17225-17237. [CrossRef]

154. Månsson, C.; Kakkar, V.; Monsellier, E.; Sourigues, Y.; Härmark, J.; Kampinga, H.H.; Melki, R.; Emanuelsson, C. DNAJB6 is a peptide-binding chaperone which can suppress amyloid fibrillation of polyglutamine peptides at substoichiometric molar ratios. Cell Stress Chaperones 2014, 19, 227-239. [CrossRef] [PubMed]

155. Morita, R.; Nishizawa, S.; Torigoe, T.; Takahashi, A.; Tamura, Y.; Tsukahara, T.; Kanaseki, T.; Sokolovskaya, A.; Kochin, V.; Kondo, T.; et al. Heat shock protein DNAJB8 is a novel target for immunotherapy of colon cancer-initiating cells. Cancer Sci. 2014, 105, 389-395. [CrossRef]

156. Yamashita, M.; Hirohashi, Y.; Torigoe, T.; Kusumoto, H.; Murai, A.; Imagawa, T.; Sato, N. Dnajb8, a Member of the Heat Shock Protein 40 Family Has a Role in the Tumor Initiation and Resistance to Docetaxel but Is Dispensable for Stress Response. PLoS ONE 2016, 11, e0146501. [CrossRef]

157. Yu, M.; Haslam, R.H.; Haslam, D.B. HEDJ, an Hsp40 co-chaperone localized to the endoplasmic reticulum of human cells. J. Biol. Chem. 2000, 275, 24984-24992. [CrossRef] [PubMed]

158. Tan, Y.L.; Genereux, J.C.; Pankow, S.; Aerts, J.M.; Yates, J.R., 3rd; Kelly, J.W. ERdj3 is an endoplasmic reticulum degradation factor for mutant glucocerebrosidase variants linked to Gaucher's disease. Chem. Biol. 2014, 21, 967-976. [CrossRef] [PubMed]

159. Cornec-Le Gall, E.; Olson, R.J.; Besse, W.; Heyer, C.M.; Gainullin, V.G.; Smith, J.M.; Audrezet, M.P.; Hopp, K.; Porath, B.; Shi, B.; et al. Monoallelic Mutations to DNAJB11 Cause Atypical Autosomal-Dominant Polycystic Kidney Disease. Am. J. Hum. Genet. 2018, 102, 832-844. [CrossRef] [PubMed]

160. Tousson-Abouelazm, N.; Papillon, J.; Guillemette, J.; Cybulsky, A.V. Urinary ERdj3 and mesencephalic astrocyte-derived neutrophic factor identify endoplasmic reticulum stress in glomerular disease. Lab. Investig. 2020, 100, 945-958. [CrossRef]

161. Hsu, C.W.; Yu, J.S.; Peng, P.H.; Liu, S.C.; Chang, Y.S.; Chang, K.P.; Wu, C.C. Secretome profiling of primary cells reveals that THBS2 is a salivary biomarker of oral cavity squamous cell carcinoma. J. Proteome Res. 2014, 13, 4796-4807. [CrossRef] [PubMed]

162. Wen, K.W.; Damania, B. Hsp90 and Hsp40/Erdj3 are required for the expression and anti-apoptotic function of KSHV K1. Oncogene 2010, 29, 3532-3544. [CrossRef]

163. Grove, D.E.; Fan, C.Y.; Ren, H.Y.; Cyr, D.M. The endoplasmic reticulum-associated Hsp40 DNAJB12 and Hsc70 cooperate to facilitate RMA1 E3-dependent degradation of nascent CFTRDeltaF508. Mol. Biol. Cell 2011, 22, 301-314. [CrossRef]

164. Sterrenberg, J.N.; Blatch, G.L.; Edkins, A.L. Human DNAJ in cancer and stem cells. Cancer Lett. 2011, 312, 129-142. [CrossRef] [PubMed]

165. Farhan, S.M.K.; Howrigan, D.P.; Abbott, L.E.; Klim, J.R.; Topp, S.D.; Byrnes, A.E.; Churchhouse, C.; Phatnani, H.; Smith, B.N.; Rampersaud, E.; et al. Exome sequencing in amyotrophic lateral sclerosis implicates a novel gene, DNAJC7, encoding a heat-shock protein. Nat. Neurosci. 2019, 22, 1966-1974. [CrossRef] [PubMed]

166. Roosen, D.A.; Blauwendraat, C.; Cookson, M.R.; Lewis, P.A. DNAJC proteins and pathways to parkinsonism. FEBS J. 2019, 286, 3080-3094. [CrossRef]

167. Hundley, H.A.; Walter, W.; Bairstow, S.; Craig, E.A. Human Mpp11 J protein: Ribosome-tethered molecular chaperones are ubiquitous. Science 2005, 308, 1032-1034. [CrossRef]

168. Aloia, L.; Demajo, S.; Di Croce, L. ZRF1: A novel epigenetic regulator of stem cell identity and cancer. Cell Cycle 2015, 14, 510-515. [CrossRef] [PubMed]

169. Richly, H.; Rocha-Viegas, L.; Ribeiro, J.D.; Demajo, S.; Gundem, G.; Lopez-Bigas, N.; Nakagawa, T.; Rospert, S.; Ito, T.; Di Croce, L. Transcriptional activation of polycomb-repressed genes by ZRF1. Nature 2010, 468, 1124-1128. [CrossRef] [PubMed]

170. Richly, H.; Di Croce, L. The flip side of the coin: Role of ZRF1 and histone H2A ubiquitination in transcriptional activation. Cell Cycle 2011, 10, 745-750. [CrossRef]

171. Ribeiro, J.D.; Morey, L.; Mas, A.; Gutierrez, A.; Luis, N.M.; Mejetta, S.; Richly, H.; Benitah, S.A.; Keyes, W.M.; Di Croce, L. ZRF1 controls oncogene-induced senescence through the INK4-ARF locus. Oncogene 2013, 32, 2161-2168. [CrossRef]

172. Demajo, S.; Uribesalgo, I.; Gutierrez, A.; Ballare, C.; Capdevila, S.; Roth, M.; Zuber, J.; Martin-Caballero, J.; Di Croce, L. ZRF1 controls the retinoic acid pathway and regulates leukemogenic potential in acute myeloid leukemia. Oncogene 2014, 33, 5501-5510. [CrossRef] [PubMed]

173. Brychzy, A.; Rein, T.; Winklhofer, K.F.; Hartl, F.U.; Young, J.C.; Obermann, W.M. Cofactor Tpr2 combines two TPR domains and a J domain to regulate the Hsp70/Hsp90 chaperone system. EMBO J 2003, 22, 3613-3623. [CrossRef]

174. Jih, K.Y.; Tsai, P.C.; Tsai, Y.S.; Liao, Y.C.; Lee, Y.C. Rapid progressive ALS in a patient with a DNAJC7 loss-of-function mutation. Neurol. Genet. 2020, 6, e503. [CrossRef]

175. Hou, Z.; Wydorski, P.M.; Perez, V.A.; Mendoza-Oliva, A.; Ryder, B.D.; Mirbaha, H.; Kashmer, O.; Joachimiak, L.A. DnaJC7 binds natively folded structural elements in tau to inhibit amyloid formation. bioRxiv 2020, 12, 5338. [CrossRef]

176. Moffatt, N.S.; Bruinsma, E.; Uhl, C.; Obermann, W.M.; Toft, D. Role of the cochaperone Tpr2 in Hsp90 chaperoning. Biochemistry 2008, 47, 8203-8213. [CrossRef] [PubMed]

177. Xiang, S.L.; Kumano, T.; Iwasaki, S.I.; Sun, X.; Yoshioka, K.; Yamamoto, K.C. The J domain of Tpr2 regulates its interaction with the proapoptotic and cell-cycle checkpoint protein, Rad9. Biochem. Biophys. Res. Commun. 2001, 287, 932-940. [CrossRef]

178. Hatakeyama, S.; Matsumoto, M.; Yada, M.; Nakayama, K.I. Interaction of U-box-type ubiquitin-protein ligases (E3s) with molecular chaperones. Genes Cells 2004, 9, 533-548. [CrossRef] 
179. Timsit, Y.E.; Negishi, M. Coordinated regulation of nuclear receptor CAR by CCRP/DNAJC7, HSP70 and the ubiquitinproteasome system. PLoS ONE 2014, 9, e96092. [CrossRef] [PubMed]

180. Li, C.; Wang, J.; Hao, J.; Dong, B.; Li, Y.; Zhu, X.; Ding, J.; Ren, S.; Zhao, H.; Wu, S.; et al. Reduced cytosolic carboxypeptidase 6 (CCP6) level leads to accumulation of serum polyglutamylated DNAJC7 protein: A potential biomarker for renal cell carcinoma early detection. Oncotarget 2016, 7, 22385-22396. [CrossRef]

181. Han, C.; Chen, T.; Li, N.; Yang, M.; Wan, T.; Cao, X. HDJC9, a novel human type C DnaJ/HSP40 member interacts with and cochaperones HSP70 through the J domain. Biochem. Biophys. Res. Commun. 2007, 353, 280-285. [CrossRef]

182. Hammond, C.M.; Bao, H.; Hendriks, I.A.; Carraro, M.; García-Nieto, A.; Liu, Y.; Reverón-Gómez, N.; Spanos, C.; Chen, L.; Rappsilber, J.; et al. DNAJC9 integrates heat shock molecular chaperones into the histone chaperone network. Mol. Cell 2021, 81, 2533-2548.e2539. [CrossRef] [PubMed]

183. Oliver, V.F.; van Bysterveldt, K.A.; Cadzow, M.; Steger, B.; Romano, V.; Markie, D.; Hewitt, A.W.; Mackey, D.A.; Willoughby, C.E.; Sherwin, T;; et al. A COL17A1 Splice-Altering Mutation Is Prevalent in Inherited Recurrent Corneal Erosions. Ophthalmology 2016, 123, 709-722. [CrossRef]

184. Liu, C.M.; Fann, C.S.; Chen, C.Y.; Liu, Y.L.; Oyang, Y.J.; Yang, W.C.; Chang, C.C.; Wen, C.C.; Chen, W.J.; Hwang, T.J.; et al. ANXA7, PPP3CB, DNAJC9, and ZMYND17 genes at chromosome 10q22 associated with the subgroup of schizophrenia with deficits in attention and executive function. Biol. Psychiatry 2011, 70, 51-58. [CrossRef]

185. Pan, Z.; Chen, S.; Pan, X.; Wang, Z.; Han, H.; Zheng, W.; Wang, X.; Li, F.; Qu, S.; Shao, R. Differential gene expression identified in Uigur women cervical squamous cell carcinoma by suppression subtractive hybridization. Neoplasma 2010, 57, 123-128. [CrossRef]

186. Liu, X.; Li, K.; Wang, L.; Zhang, M.; Wang, X. Variations of human heat shock proteins in multiple cancers. Clin. Transl. Med. 2021, 11, e320. [CrossRef] [PubMed]

187. Mandriani, B.; Castellana, S.; Rinaldi, C.; Manzoni, M.; Venuto, S.; Rodriguez-Aznar, E.; Galceran, J.; Nieto, M.A.; Borsani, G.; Monti, E.; et al. Identification of p53-target genes in Danio rerio. Sci. Rep. 2016, 6, 32474. [CrossRef]

188. Anikster, Y.; Haack, T.B.; Vilboux, T.; Pode-Shakked, B.; Thony, B.; Shen, N.; Guarani, V.; Meissner, T.; Mayatepek, E.; Trefz, F.K.; et al. Biallelic Mutations in DNAJC12 Cause Hyperphenylalaninemia, Dystonia, and Intellectual Disability. Am. J. Hum. Genet. 2017, 100, 257-266. [CrossRef]

189. Li, M.; Yang, Q.; Yi, S.; Qin, Z.; Luo, J.; Fan, X. Two novel mutations in DNAJC12 identified by whole-exome sequencing in a patient with mild hyperphenylalaninemia. Mol. Genet. Genom. Med. 2020, 8, e1303. [CrossRef]

190. Gallego, D.; Leal, F.; Gámez, A.; Castro, M.; Navarrete, R.; Sanchez-Lijarcio, O.; Vitoria, I.; Bueno-Delgado, M.; BelangerQuintana, A.; Morais, A.; et al. Pathogenic variants of DNAJC12 and evaluation of the encoded cochaperone as a genetic modifier of hyperphenylalaninemia. Hum. Mutat. 2020, 41, 1329-1338. [CrossRef] [PubMed]

191. Fan, Y.; Yang, Z.H.; Li, F.; Hu, X.C.; Yue, Y.W.; Yang, J.; Liu, Y.T.; Liu, H.; Wang, Y.L.; Shi, C.H.; et al. DNAJC12 mutation is rare in Chinese Han population with Parkinson's disease. Neurobiol. Aging. 2018, 68, e151-e159. [CrossRef]

192. He, H.L.; Lee, Y.E.; Chen, H.P.; Hsing, C.H.; Chang, I.W.; Shiue, Y.L.; Lee, S.W.; Hsu, C.T.; Lin, L.C.; Wu, T.F.; et al. Overexpression of DNAJC12 predicts poor response to neoadjuvant concurrent chemoradiotherapy in patients with rectal cancer. Exp. Mol. Pathol. 2015, 98, 338-345. [CrossRef]

193. Uno, Y.; Kanda, M.; Miwa, T.; Umeda, S.; Tanaka, H.; Tanaka, C.; Kobayashi, D.; Suenaga, M.; Hattori, N.; Hayashi, M.; et al. Increased Expression of DNAJC12 is Associated with Aggressive Phenotype of Gastric Cancer. Ann. Surg. Oncol. 2019, 26, 836-844. [CrossRef] [PubMed]

194. Li, Y.; Li, M.; Jin, F.; Liu, J.; Chen, M.; Yin, J. DNAJC12 promotes lung cancer growth by regulating the activation of $\beta$-catenin. Int. J. Mol. Med. 2021, 47, 105. [CrossRef]

195. Hatle, K.M.; Gummadidala, P.; Navasa, N.; Bernardo, E.; Dodge, J.; Silverstrim, B.; Fortner, K.; Burg, E.; Suratt, B.T.; Hammer, J.; et al. MCJ/DnaJC15, an endogenous mitochondrial repressor of the respiratory chain that controls metabolic alterations. Mol. Cell Biol. 2013, 33, 2302-2314. [CrossRef]

196. Sinha, D.; D'Silva, P. Chaperoning mitochondrial permeability transition: Regulation of transition pore complex by a J-protein, DnaJC15. Cell Death Dis. 2014, 5, e1101. [CrossRef]

197. Lindsey, J.C.; Lusher, M.E.; Strathdee, G.; Brown, R.; Gilbertson, R.J.; Bailey, S.; Ellison, D.W.; Clifford, S.C. Epigenetic inactivation of MCJ (DNAJD1) in malignant paediatric brain tumours. Int. J. Cancer 2006, 118, 346-352. [CrossRef]

198. Lau, D.T.; Hesson, L.B.; Norris, M.D.; Marshall, G.M.; Haber, M.; Ashton, L.J. Prognostic significance of promoter DNA methylation in patients with childhood neuroblastoma. Clin. Cancer Res. 2012, 18, 5690-5700. [CrossRef]

199. Schusdziarra, C.; Blamowska, M.; Azem, A.; Hell, K. Methylation-controlled J-protein MCJ acts in the import of proteins into human mitochondria. Hum. Mol. Genet. 2013, 22, 1348-1357. [CrossRef] [PubMed]

200. Alessandrini, F.; Pezze, L.; Menendez, D.; Resnick, M.A.; Ciribilli, Y. ETV7-Mediated DNAJC15 Repression Leads to Doxorubicin Resistance in Breast Cancer Cells. Neoplasia 2018, 20, 857-870. [CrossRef] [PubMed]

201. Witham, J.; Vidot, S.; Agarwal, R.; Kaye, S.B.; Richardson, A. Transient ectopic expression as a method to detect genes conferring drug resistance. Int. J. Cancer 2008, 122, 2641-2645. [CrossRef] [PubMed]

202. Fernandez-Cabezudo, M.J.; Faour, I.; Jones, K.; Champagne, D.P.; Jaloudi, M.A.; Mohamed, Y.A.; Bashir, G.; Almarzooqi, S.; Albawardi, A.; Hashim, M.J.; et al. Deficiency of mitochondrial modulator MCJ promotes chemoresistance in breast cancer. JCI Insight 2016, 1, e86873. [CrossRef] [PubMed] 
203. Hatle, K.M.; Neveu, W.; Dienz, O.; Rymarchyk, S.; Barrantes, R.; Hale, S.; Farley, N.; Lounsbury, K.M.; Bond, J.P.; Taatjes, D.; et al. Methylation-controlled J protein promotes c-Jun degradation to prevent ABCB1 transporter expression. Mol. Cell Biol. 2007, 27, 2952-2966. [CrossRef]

204. Liu, T.; Jiang, W.; Han, D.; Yu, L. DNAJC25 is downregulated in hepatocellular carcinoma and is a novel tumor suppressor gene. Oncol. Lett. 2012, 4, 1274-1280. [CrossRef]

205. Acun, T. DNAJC25 as a tumor suppressor candidate gene in breast cancer. Hacet. J. Biol. Chem. 2021, 49, 305. [CrossRef]

206. Pinhasi-Kimhi, O.; Michalovitz, D.; Ben-Zeev, A.; Oren, M. Specific interaction between the p53 cellular tumour antigen and major heat shock proteins. Nature 1986, 320, 182-184. [CrossRef] [PubMed]

207. Hinds, P.W.; Finlay, C.A.; Frey, A.B.; Levine, A.J. Immunological evidence for the association of p53 with a heat shock protein, hsc70, in p53-plus-ras-transformed cell lines. Mol. Cell Biol. 1987, 7, 2863-2869. [CrossRef]

208. Hansen, S.; Hupp, T.R.; Lane, D.P. Allosteric regulation of the thermostability and DNA binding activity of human p53 by specific interacting proteins. CRC Cell Transformation Group. J. Biol. Chem. 1996, 271, 3917-3924. [CrossRef]

209. Walerych, D.; Olszewski, M.B.; Gutkowska, M.; Helwak, A.; Zylicz, M.; Zylicz, A. Hsp70 molecular chaperones are required to support p53 tumor suppressor activity under stress conditions. Oncogene 2009, 28, 4284-4294. [CrossRef]

210. Walerych, D.; Kudla, G.; Gutkowska, M.; Wawrzynow, B.; Muller, L.; King, F.W.; Helwak, A.; Boros, J.; Zylicz, A.; Zylicz, M. Hsp90 chaperones wild-type p53 tumor suppressor protein. J. Biol. Chem. 2004, 279, 48836-48845. [CrossRef] [PubMed]

211. Boysen, M.; Kityk, R.; Mayer, M.P. Hsp70- and Hsp90-Mediated Regulation of the Conformation of p53 DNA Binding Domain and p53 Cancer Variants. Mol. Cell 2019, 74, 831-843.e834. [CrossRef]

212. Trinidad, A.G.; Muller, P.A.; Cuellar, J.; Klejnot, M.; Nobis, M.; Valpuesta, J.M.; Vousden, K.H. Interaction of p53 with the CCT complex promotes protein folding and wild-type p53 activity. Mol. Cell 2013, 50, 805-817. [CrossRef] [PubMed]

213. Zhang, W.; Deisseroth, A.B. Conformational change of p53 protein in growth factor-stimulated human myelogenous leukemia cells. Leuk. Lymphoma 1994, 14, 251-255. [CrossRef]

214. Zheng, A.; Castren, K.; Saily, M.; Savolainen, E.R.; Koistinen, P.; Vahakangas, K. p53 status of newly established acute myeloid leukaemia cell lines. Br. J. Cancer 1999, 79, 407-415. [CrossRef] [PubMed]

215. Arandkar, S.; Furth, N.; Elisha, Y.; Nataraj, N.B.; van der Kuip, H.; Yarden, Y.; Aulitzky, W.; Ulitsky, I.; Geiger, B.; Oren, M. Altered p53 functionality in cancer-associated fibroblasts contributes to their cancer-supporting features. Proc. Natl. Acad. Sci. USA 2018, 115, 6410-6415. [CrossRef]

216. Benor, G.; Fuks, G.; Chin, S.F.; Rueda, O.M.; Mukherjee, S.; Arandkar, S.; Aylon, Y.; Caldas, C.; Domany, E.; Oren, M. Transcriptional profiling reveals a subset of human breast tumors that retain wt TP53 but display mutant p53-associated features. Mol. Oncol. 2020, 14, 1640-1652. [CrossRef]

217. Tuval, A.B.Y.; Azogy, H.; Moshkovitz, Y.; Biezuner, T.; Leshkowitz, D.; Salame, T.M.; Minden, M.D.; Tal, P.; Rotter, V.; Oren, M.; et al. Pseudo-mutant p53 as a targetable phenotype of DNMT3A-mutated pre-leukemia. bioRxiv 2021. [CrossRef]

218. Akakura, S.; Yoshida, M.; Yoneda, Y.; Horinouchi, S. A role for Hsc70 in regulating nucleocytoplasmic transport of a temperaturesensitive p53 (p53Val-135). J. Biol. Chem. 2001, 276, 14649-14657. [CrossRef] [PubMed]

219. Nikolova, P.V.; Wong, K.B.; DeDecker, B.; Henckel, J.; Fersht, A.R. Mechanism of rescue of common p53 cancer mutations by second-site suppressor mutations. EMBO J. 2000, 19, 370-378. [CrossRef]

220. Gomes, S.; Bosco, B.; Loureiro, J.B.; Ramos, H.; Raimundo, L.; Soares, J.; Nazareth, N.; Barcherini, V.; Domingues, L.; Oliveira, C.; et al. SLMP53-2 Restores Wild-Type-Like Function to Mutant p53 through Hsp70: Promising Activity in Hepatocellular Carcinoma. Cancers 2019, 11, 1151. [CrossRef]

221. Selivanova, G.; Kawasaki, T.; Ryabchenko, L.; Wiman, K.G. Reactivation of mutant p53: A new strategy for cancer therapy. Semin. Cancer Biol. 1998, 8, 369-378. [CrossRef] [PubMed]

222. Rokaeus, N.; Klein, G.; Wiman, K.G.; Szekely, L.; Mattsson, K. PRIMA-1(MET) induces nucleolar accumulation of mutant p53 and PML nuclear body-associated proteins. Oncogene 2007, 26, 982-992. [CrossRef] [PubMed] 